INTERNATIONAL MONETARY FUND

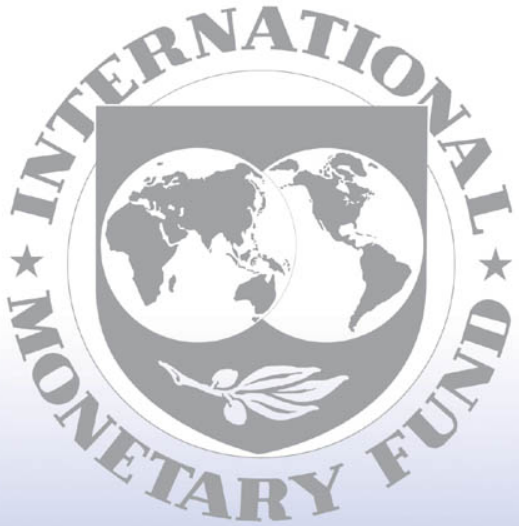

Staff

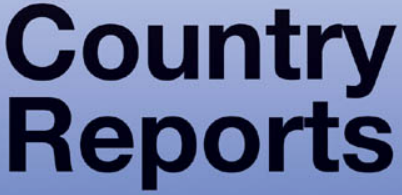




\section{People's Republic of China: 2010 Article IV Consultation-Staff Report; Staff Statement; Public Information Notice on the Executive Board Discussion}

Under Article IV of the IMF's Articles of Agreement, the IMF holds bilateral discussions with members, usually every year. In the context of the 2010 Article IV consultation with the People's Republic of China, the following documents have been released and are included in this package:

- $\quad$ The staff report for the 2010 Article IV consultation, prepared by a staff team of the IMF, following discussions that ended on July 1, 2010, with the officials of the People's Republic of China on economic developments and policies. Based on information available at the time of these discussions, the staff report was completed on July 9, 2010. The views expressed in the staff report are those of the staff team and do not necessarily reflect the views of the Executive Board of the IMF;

- $\quad$ A staff statement of July 26, 2010 updating information on recent developments; and

- $\quad$ A Public Information Notice (PIN) summarizing the views of the Executive Board as expressed during its July 26, 2010 discussion of the staff report that concluded the Article IV consultation.

The policy of publication of staff reports and other documents allows for the deletion of market-sensitive information.

Copies of this report are available to the public from

International Monetary Fund • Publication Services

$70019^{\text {th }}$ Street, N.W. • Washington, D.C. 20431

Telephone: (202) 623-7430 • Telefax: (202) 623-7201

E-mail: publications@imf.org Internet: http://www.imf.org

Price: $\$ 18.00$ a copy

\section{International Monetary Fund Washington, D.C.}




\section{INTERNATIONAL MONETARY FUND}

\section{PEOPLE'S REPUBLIC OF CHINA}

\section{Staff Report for the 2010 Article IV Consultation}

Prepared by the Staff Representatives for the 2010 Article IV Consultation with the People's Republic of China

Approved by Anoop Singh and Tamim Bayoumi

July 9,2010

Mission. A staff team consisting of N. Chalk (Head), A. Ahuja, S. Barnett, P. N'Diaye, N. Porter, M. Syed (APD), R. Duttagupta (SPR), I. Lee, and T. Feyzioğlu (Resident Representatives) visited Beijing, Lanzhou, and Shanghai from June 17 to July 1, 2010. Messrs. He and Zhang (OED) joined the mission and Mr. Shinohara and Mr. Singh participated in the senior policy meetings. The mission overlapped with a joint MCM-World Bank mission that began work on the Financial Sector Assessment Program for China.

Outlook. The recovery has taken hold and growth should be in the double digits this year. Barring further food supply shocks, inflation will peak by mid-year and then slowly decline. The current account surplus continues to fall and is now around one-half of its 2007 peak. However, over the medium-term, there is a potential for sizable current account surpluses to return as the policy stimulus is wound down and the global economy recovers.

Risks. The main risks facing the Chinese economy include a renewed weakening in the global recovery, a worsening of credit quality (notably from an expansion of lending to local governments), or a misstep in the government's response to rising property prices.

Rebalancing. A range of policies will be needed to ensure a sustained rebalancing of growth toward private consumption. These include measures to reform and liberalize the financial system, fiscal support for household consumption, an expansion of the social safety net, policies to capitalize on the ongoing process of urbanization, developing the service sector, structural changes to lower corporate savings, and an appreciation of the renminbi. There has been important progress in many of these areas but more remains to be done.

Past advice. The authorities broadly agree with the Fund's advice on the need to rebalance toward domestic sources of growth, but there have been different views on the appropriate pace of some reforms. 
Executive Summary

I. How has China Handled the Global Financial Crisis? ..........................................................

II. Has the Crisis Response Exacerbated Existing Vulnerabilities? .........................................

A. Has the Policy Stimulus Created a Risk of Overheating? ........................................ 9

B. What are the Emerging Risks in the Property Sector? ...........................................11

C. What are the Vulnerabilities in Local Governments' Fiscal Positions?....................15

D. How has the Credit Expansion Affected the Banks? ............................................

III. Where is the Chinese Economy Heading Over a Longer Horizon? .................................16

A. Will the Decline in the Current Account Surplus Endure? ......................................

B. How can Recent Gains in Consumption Growth be Sustained? ..............................20

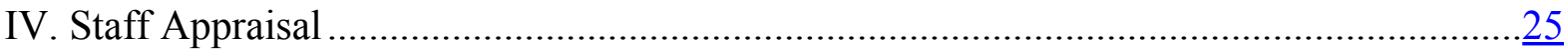

Boxes

1. Further Reform of the Renminbi Exchange Rate Regime ……….....................................

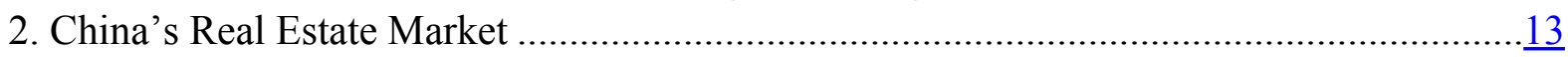

3. Key Lessons from Recent Japanese History ...............................................................14

4. Prospects for the Current Account Surplus...................................................................

5. The Inter-Provincial Impact of Exchange Rate Changes....................................................

Figures

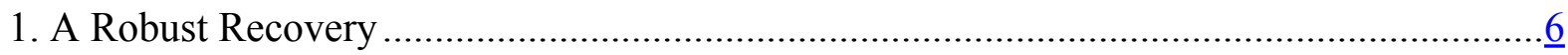

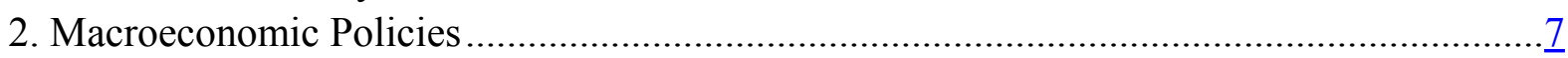

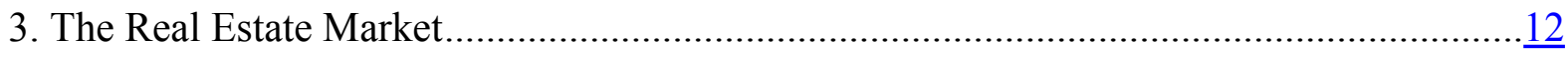

4. The Decline in the Current Account Surplus ...............................................................

Tables

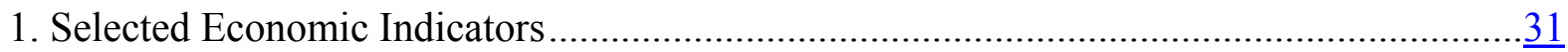

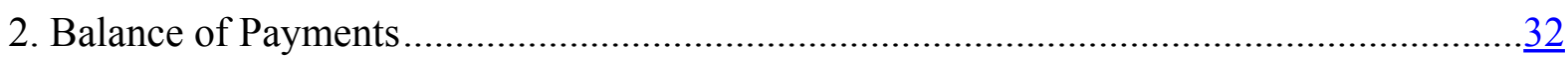

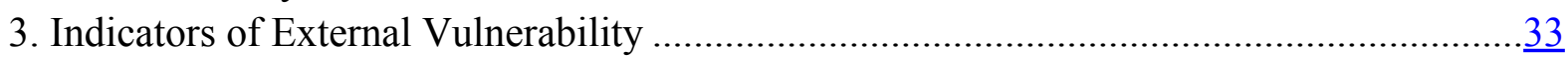

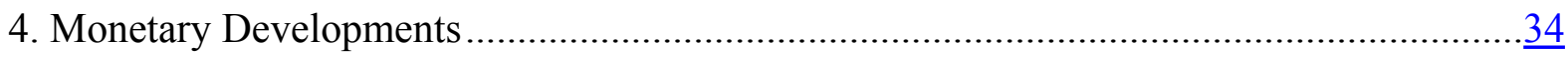

5. General Government Budgetary Operations............................................................

6. Illustrative Medium-Term Scenario.........................................................................

7. Public Sector Debt Sustainability Framework ……………………….............................37 


\section{EXECUTIVE SUMMARY}

A strong fiscal response and an expansionary monetary policy have ensured that China has led the global recovery. At the same time, important progress has been made in a range of structural areas which will contribute to a rebalancing of the economy. The challenge now will be to sustain this strong growth performance while switching decisively to an economy that is powered by the Chinese consumer. Much has been done but, given the complexity of the task at hand, a broad agenda remains ahead and includes:

- Maintaining the fiscal stimulus through 2010 while, on the margin, reorienting further toward fiscal measures that will spur consumption. If the recovery continues as envisaged, begin gradually withdrawing fiscal stimulus in 2011 while continuing to expand near-term fiscal support for consumption.

- Continuing to withdraw monetary stimulus to return credit growth to more normal levels. In doing so, a greater role for interest rates, open market operations, and reserve requirements is warranted.

- Maintaining supervisory and regulatory vigilance to identify and manage any deterioration in credit quality that may arise from last year's credit expansion.

- Increasing the transparency and availability of information on local government financing vehicles. Strictly enforcing the existing prohibition of local government debt guarantees.

- Continuing to deploy prudential measures to counter unwarranted growth in real estate prices. Introducing a property tax and, over time, raising the cost of capital to lessen the propensity for property price bubbles.

- Using the flexibility in the current exchange rate regime to allow for an appreciation of the renminbi in real effective terms.

- Liberalizing the financial system with an eventual phase-out of deposit rate ceilings and of direct limits on credit growth.

- Developing a broader range of financial markets and investment products to raise household capital income, offer households alternative investment and insurance products, and lessen the demand for physical assets (such as housing) as a store of value.

- Sustaining the recent pace of progress in building out China's social safety net, particularly in health, education, and pensions.

- Capitalizing on urbanization as a force for growth and rebalancing. This would include reducing labor market rigidities, investing in urban infrastructure, rural land reform, and removing barriers to competition in the service economy.

- Tackling high corporate saving by raising the costs of factor inputs (including capital), widening corporate ownership, boosting dividend payouts, and increasing competition in domestic markets. 


\section{How has China Handled the Global Financial Crisis?}

1. The crisis response. China was hit hard by the global financial crisis, predominantly through trade channels. The policy response was quick, determined, and effective and comprised three broad strands:

- A major fiscal stimulus. The public stimulus was concentrated in infrastructure spending, drawing on the government's successful use of capital spending as a countercyclical tool during the Asian financial crisis. The government did, however, devote an estimated 2-3 percent of GDP to higher social spending and incentiveslargely on the tax side - to support private consumption.

- An extraordinary credit expansion. Chinese banks extended new loans of 31 percent of GDP in 2009. This outturn was largely a result of the removal of limits on credit growth, supported by a relaxation of restrictions on property lending and a reduction in both interest rates and reserve requirements.

- $\quad$ Re-pegging the renminbi to the U.S. dollar. In July 2005, the central bank began to allow the renminbi to appreciate against the U.S. dollar, at its peak reaching a rate of appreciation of around 1 percent per month. However, in response to increasing volatility in the world economy and in global financial markets, the central bank returned to pegging the renminbi to the U.S. dollar in July 2008.

2. Outcomes. This policy package was instrumental in mitigating the effects of the shock to external demand and in arresting the downward momentum to both activity and confidence (Figure 1).

- Growth began to pick up in the second quarter of 2009 and reached an average for the year of 9.1 percent, around half of which is estimated to be due to public spending.

- Inflation moved into negative territory for much of 2009 but has since registered a modest increase. The bulk of this inflation has been directly attributable to higher food prices.

- $\quad$ The balance of payments saw an unprecedented and dramatic change. The current account fell quickly as export volumes fell and imports surged. The terms of trade also moved against China, accentuating the decline in the trade Since late 2009 inflation has resumed surplus. On the capital account side, foreign direct investment fell, in line with global trends.

- $\quad$ Despite the lower current account and reduced FDI inflows, reserve accumulation continued to be rapid, reaching over US $\$ 40$ billion per month in the year to March. 
3. Spillovers. China's recovery had significant positive trade spillovers to the region and the global economy, initially through increased demand for commodities-which contributed to an upswing in global commodity prices - and later through higher imports of capital goods (notably from Japan, Korea, Germany, and Taiwan Province of China).

4. $\quad$ Exit. The government has started to unwind many of its crisis response measures (Figure 2). Credit growth is being slowed; prudential requirements related to property lending are being tightened; and the government announced it would return to the managed floating exchange rate regime that was in place from July 2005 to July 2008 (Box 1).

\section{Box 1: Further Reform of the Renminbi Exchange Rate Regime}

- On June 19, 2010 the People's Bank of China announced the return to a managed floating exchange rate regime that allows for movements in the exchange rate based upon market supply and demand and with reference to a basket of currencies.

- Under this regime, the U.S. dollar-renminbi spot exchange rate can move intraday \pm 0.5 percent from a central parity (that is determined at the opening of trading by a truncated weighted average of primary dealers' offer rates and is announced by the China Foreign Exchange Trading System). The central parity itself has not moved by more than \pm 0.5 percent each day.

- In the 3 weeks since the reform was announced, the currency has appreciated against the U.S. dollar by $3 / 4$ percent

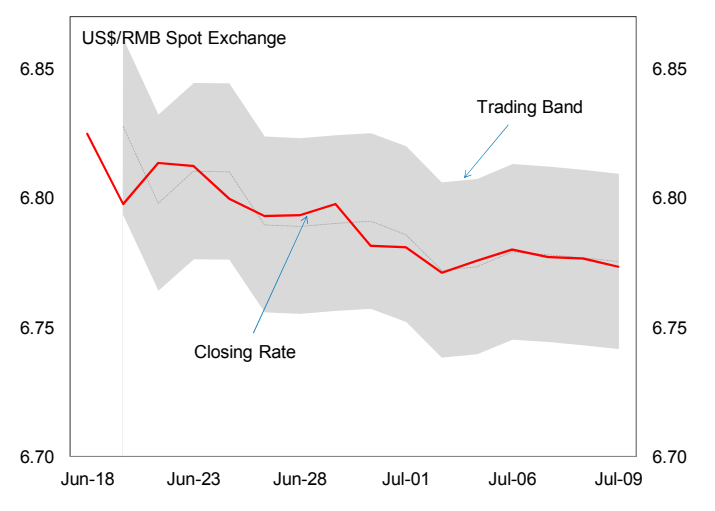
depreciating $1 / 4$ percent in nominal effective terms. 
Figure 1. A Robust Recovery

Main Message: The recovery is well established with increasing signs of a transition from public stimulus to private sector-led growth.

The economic recovery began early and has proceeded at a fast pace.

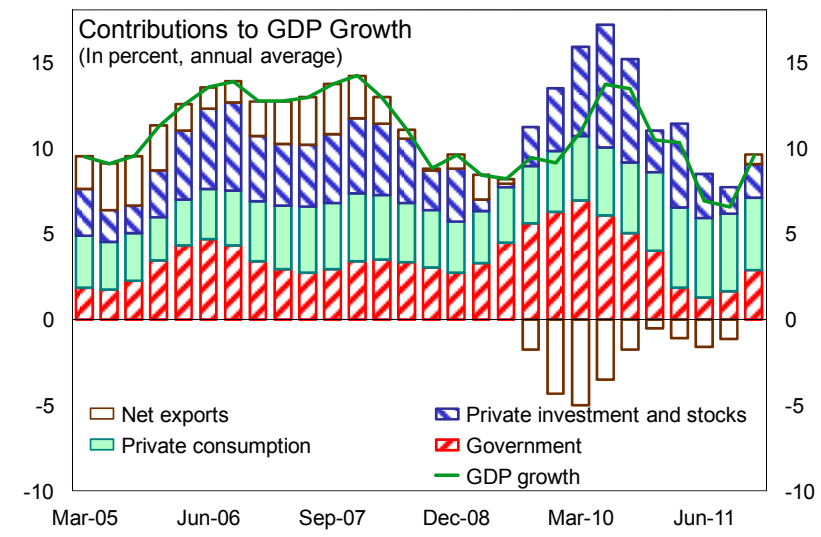

...while the surge in investment has been extraordinary.

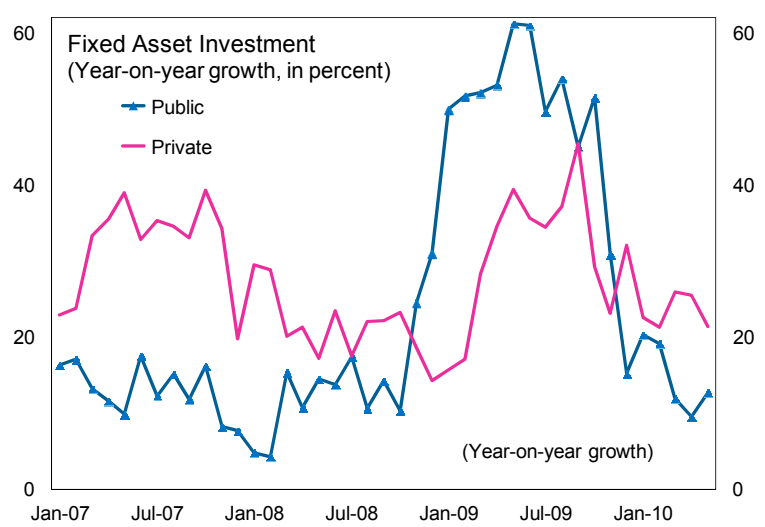

The export rebound has, however, been outstripped by import demand.

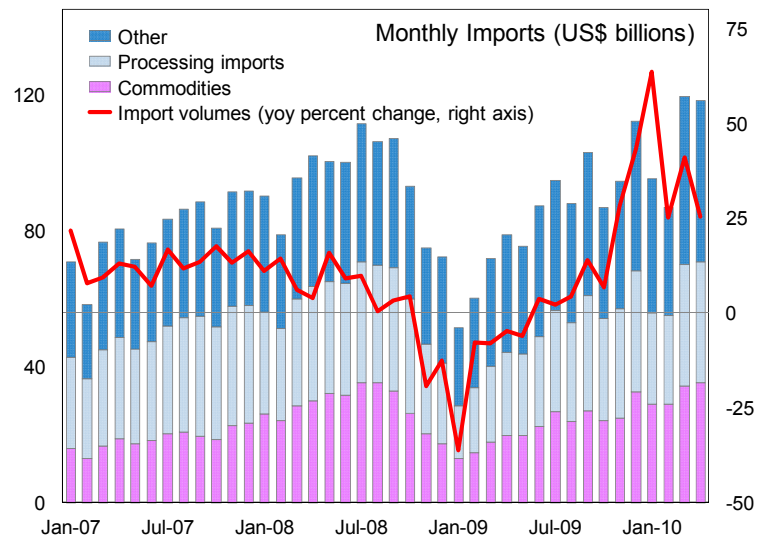

Consumption growth has been vigorous, helped by robust labor markets and government policies,...

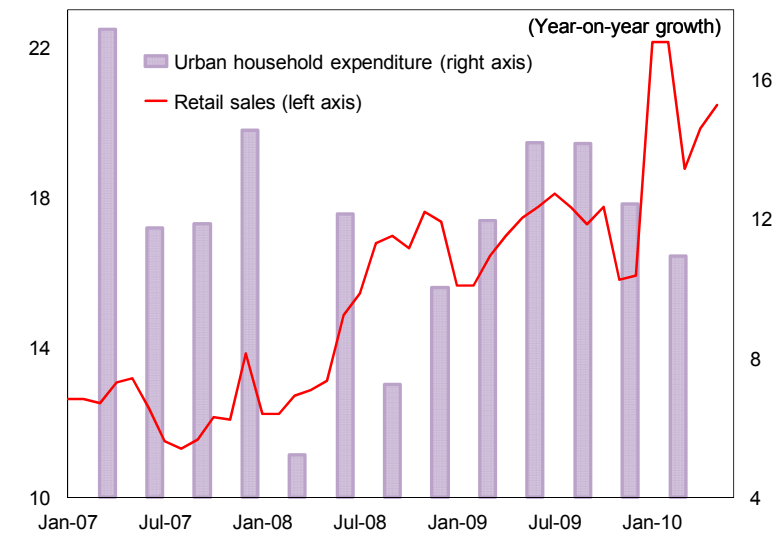

Exports are above their pre-crisis levels with particular strength in electronics and light manufacturing.

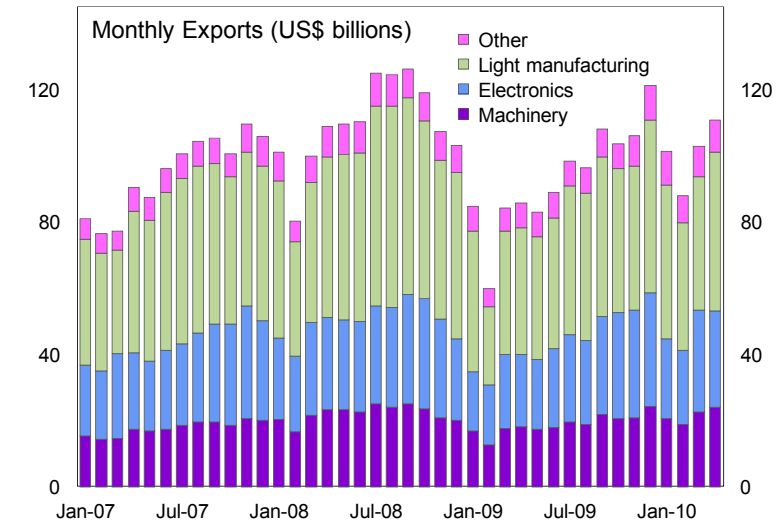

Forward-looking indicators show continued growth momentum, albeit slowing modestly in recent months.

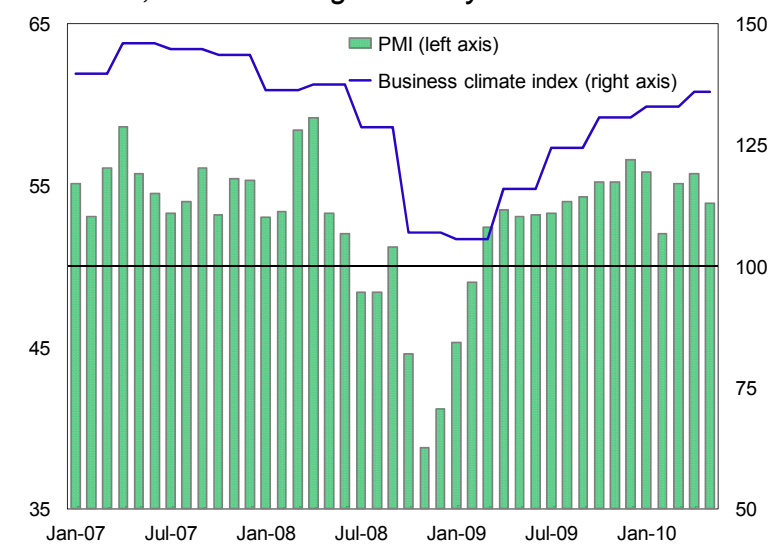

Sources: Bloomberg; CEIC Data Company Ltd.; and staff estimates. 
Figure 2. Macroeconomic Policies

Main Message: The policy challenge now is to correctly calibrate the pace and sequencing of exit from the extraordinary support that was given to the economy during the global financial crisis.

In late 2008, restrictions on loan growth were removed allowing the fiscal stimulus to be financed by bank credit.

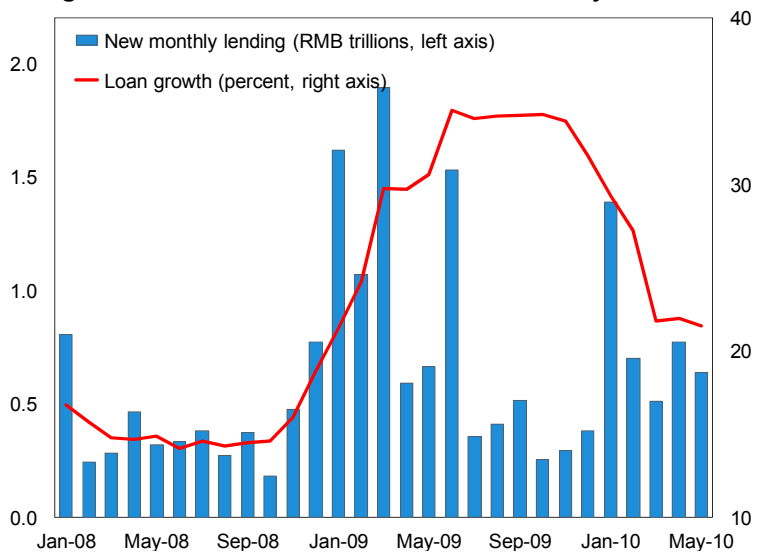
..supported by foreign currency intervention.

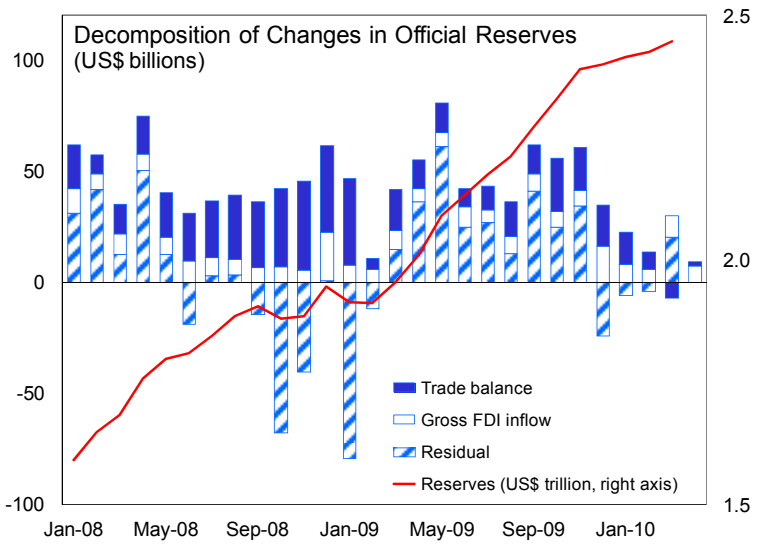

...driven by higher capital spending, a large part of which took place at the local government level.

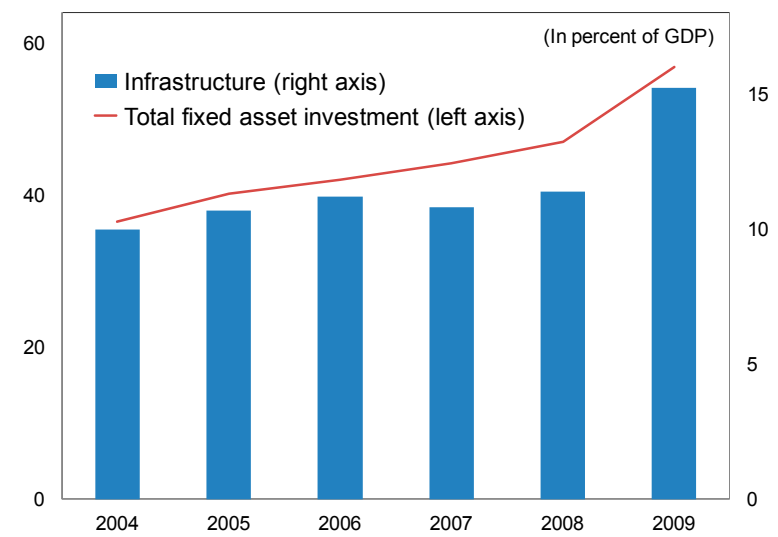

The renminbi was re-pegged to the US dollar...

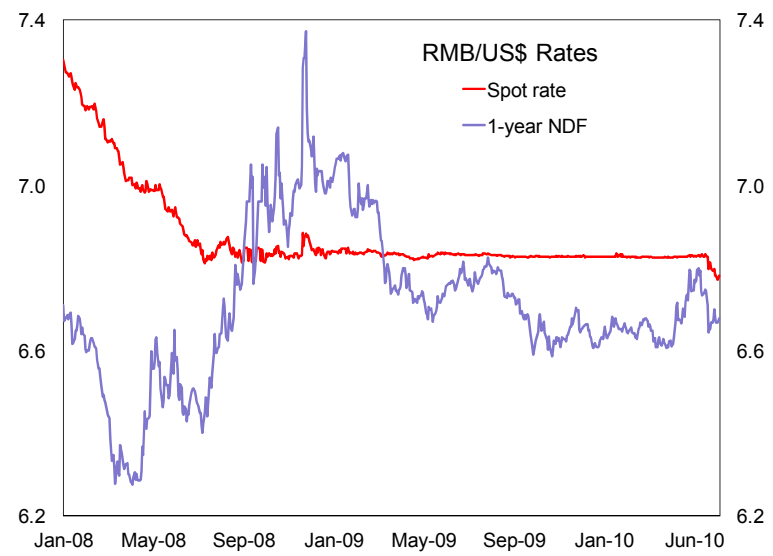

A significant fiscal stimulus was quickly put in place...

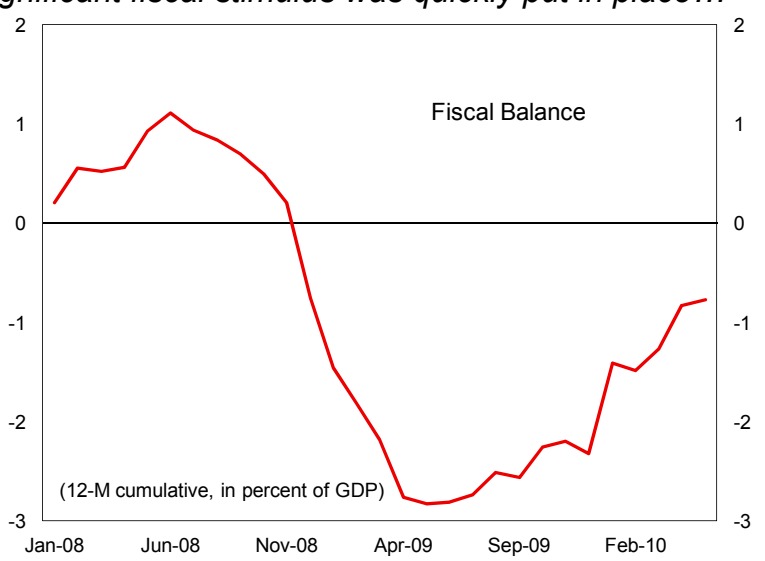

The monetary expansion is now being steadily scaled back, largely through the re-imposition of limits on credit growth.

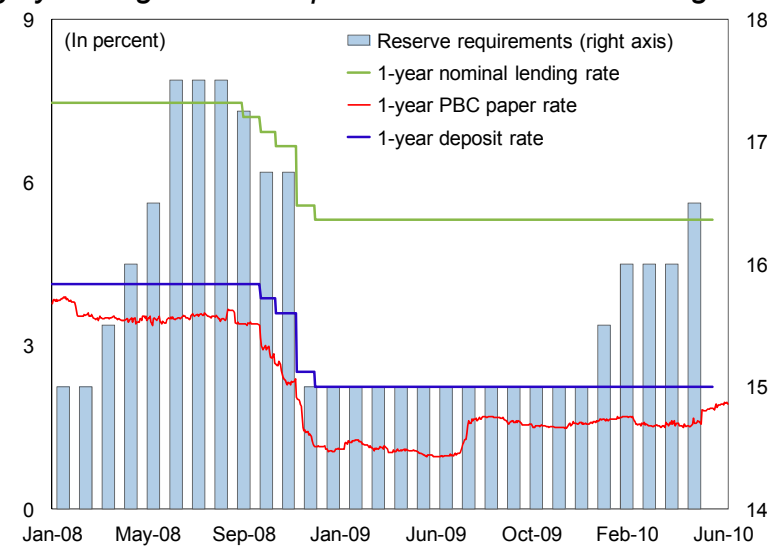

Sources: Bloomberg; CEIC Data Company Ltd.; and staff estimates. 
5. Monetary policy. The central bank's loosening of monetary policy in response to the global financial crisis served to support growth and mobilize the resources needed to finance a surge in investment. However, the rapid expansion in credit has led to an increased risk of a worsening in credit quality. With China's economic recovery now firmly established, the need for monetary support has greatly diminished. The central bank is, therefore, targeting a reduction in M2 growth from 28 percent at end-2009 to 17 percent by end-2010. This will imply an increase in new lending of around Y7.5 trillion for the year as a whole. To achieve that goal, the central bank has increased reserve requirements three times this year (from 15.5 to 17 percent, for the large commercial banks). In addition, domestic liquidity conditions have been tightened through the stepped-up issuance of central bank bonds. However, benchmark interest rates have yet to move upwards and the government continues to rely on quantitative limits to slow credit growth. The targeted reduction in the pace of credit growth is fully appropriate. However, staff argued for a broader range of tools to be used with a greater reliance placed on interest rates, open market operations, and reserve requirements. Central bank officials indicated that they are fully committed to a greater use of indirect monetary policy instruments. They noted, however, that, with a benign inflation outlook, there was less need for higher nominal interest rates at this point. Also, as a secondary factor, they were concerned that higher interest rates could risk fueling capital inflows.

6. Fiscal policy. The 2010 budget targets a deficit of 3 percent of GDP, which should support a steady resumption of private demand. This fiscal stimulus has come through a combination of infrastructure spending, a reduction in the tax burden, and incentives to boost purchases of consumer durables and autos. In addition, pensions, social transfers, healthcare, and education spending have all been increased in an effort to support household income and improve people's livelihoods. Beyond the fiscal impulse evident in the higher general government deficit, a significant amount of support was also provided to the economy through capital spending by local government financing vehicles and state-owned enterprises. There was agreement that further mechanisms should be sought to continue to reorient spending toward measures that would boost household income and consumption, within the existing budget envelope. Staff noted that revenue performance had been strong in the first half of 2010 and that this should afford considerable scope for additional measures to encourage consumption while still staying within the deficit target for the year as a whole. For 2011, the authorities indicated they have yet to decide the fiscal stance but noted that any eventual withdrawal of

Measures to Boost Household Income and Consumption

- Increases in the basic pension, social transfers, and unemployment benefits.

- Consumption subsidies for the purchase of autos, motorcycles, and home appliances.

- Incentives to trade-in autos and motorcycles for more energy efficient models.

- Lower tax rate on the purchase of smaller autos.

- Exemption of stamp duty for the purchase of smaller first homes.

- Delayed payment of social security contributions.

- Skill training for the unemployed and migrant workers.

- Subsidized college tuition for rural students. 
stimulus would be measured and gradual. On the other hand, if the global recovery falters, there was a shared view that China should turn once again to fiscal tools to offset the resultant shock to external demand. Over a longer horizon, the authorities' preference was to gravitate back toward budget balance, noting that China's strong fiscal position going into the global crisis had afforded it the space needed to respond forcefully to the shock to external demand. Staff agreed that such an approach to the setting of fiscal policy in the coming years was fully appropriate.

7. The exchange rate. The authorities characterized their decision to return to a managed floating regime as part of an effort to overcome the temporary interruption to the reform process that was caused by the global financial crisis. They emphasized the marketdetermined nature of the exchange rate under the managed floating regime and indicated that they are prepared to allow the exchange rate to respond more to the forces of demand and supply. Staff agreed that the return to the pre-crisis regime would afford the central bank significant flexibility and greater monetary policy independence. Going forward, it would be important to allow movements in the exchange rate to assist in the ongoing tightening of monetary conditions.

8. External risks. There was broad agreement that the principal near-term risk facing the Chinese recovery is the possibility of a renewed downswing in the global economy. The authorities indicated that events in Europe have increased concerns within China about the sustainability of the global recovery, inducing greater caution in the pace of exit from the government's crisis response measures. Over a longer horizon, they were also concerned that the process of fiscal consolidation in Europe, Japan, and the U.S. had the potential to lower global growth with longer-lasting negative spillovers to China. The authorities indicated they were watching carefully for a decisive approach to tackling the unsustainable sovereign debt trajectory in a range of countries and that they would also favor early publication of bank stress tests in Europe. Finally, they indicated their full support for the G-20 mutual assessment process - and the important role of the IMF - as a means to achieve a more coordinated approach to global economic policy.

\section{Has the CRisis Response ExaCerbated Existing Vulnerabilities?}

\section{A. Has the Policy Stimulus Created a Risk of Overheating?}

9. Context. Monetary aggregates have been growing at a very fast pace. At the same time, the growth rebound has been rapid. This has raised concerns by some analysts that the output gap may now be closing in China and inflationary pressures may rise in the period ahead. Indeed, after a period of deflation in 2009, prices have moved on to an upward trajectory and inflation is now around 3 percent.

10. What drives inflation in China? Aside from periodic bouts of food inflation, prices in China have been remarkably stable since the end of the high inflation in the late 1990s. 
This is despite rapid economic and monetary growth throughout that period. Empirical work suggests that the output gap is not a major predictor of inflation in China. ${ }^{1}$ This finding is robust for several different measures of the output gap. Staff interpret this result as an indication that, over much of the past decade, China has been on the flatter part of the inflation-output trade-off, with the economy operating away from potential output. However, empirical work suggests that foreign demand and rising commodity prices do affect nonfood inflation. In particular, a 1 percent increase in foreign demand or a 20 percent increase in world commodity prices would each raise nonfood inflation by around $1 / 2$ percent.

Movements in food inflation, on the other hand, appear to be largely a result of supply shocks to agriculture.

11. What about wages? China has recently seen some high profile labor disputes that have been resolved with significant increases in nominal wages. At the same time, there are reports of labor shortages in some of the coastal areas. Discussions with the private sector indicated that while nominal wages were rising in the 10-15 percent range, this was a reasonably similar pattern to that of previous years and represented more an indication of the high level of productivity growth rather than tightness in the labor market. Indeed, historically, there appears to be relatively little pass-through from higher wages to domestic inflation with the costs being absorbed either through productivity gains or within companies' existing margins. In addition, facilitated by ongoing investments in infrastructure, jobs are continuing to move toward the interior of the country where wages are lower. This will be a structural force for some time to come that will help put downward pressure on average labor costs. The authorities agreed that labor market conditions were stable and that, for the nation as a whole, there was still an excess supply of labor (which would restrain wage pressures). There was broad agreement that steadily rising real wages were a healthy development that would ultimately boost household income and promote consumption, leading to a more balanced economy.

12. Outlook. Looking forward, the massive investment program put in place since late 2008, continued high levels of investment, and significant productivity growth will continue to neutralize demand pressures in the near term. Staff forecasts that inflation will soon peak and converge to a level of around 2-3 percent over the next few years, even after accounting for stronger external demand and the IMF's forecast for global commodity prices. In addition, producer price inflation should also begin to fall in the coming months. However, it is worth noting that, since the housing component in the CPI is linked to rental and actual mortgage costs, nonfood inflation does not fully capture the underlying cost of living associated with rising housing costs.

\footnotetext{
${ }^{1}$ See N. Porter, "Inflation Dynamics in China,” IMF Working Paper (forthcoming).
} 


\section{B. What are the Emerging Risks in the Property Sector?}

13. Context. The government's removal of constraints on lending to residential real estate and lowering of real estate transaction taxes was effective in fostering a turnaround in both construction and property prices (Figure 3). However, attention is now shifting to whether this policy response has created a situation where housing prices are rising faster than would be justified by underlying fundamentals. Housing affordability is also becoming an increasingly prominent social issue.

14. Is there a risk of a bubble? Low real returns on bank deposits and a lack of alternative investment vehicles mean that residential real estate presents an attractive destination for China's high domestic saving. Nonetheless, at a national level, it does not seem as if property prices are significantly above fundamentals (Box 2). However, a property bubble is beginning to inflate in some of the larger cities and there has been an uptick in credit to the real estate sector. As a result, preemptive action is warranted.

15. Policy implications. The Chinese authorities are acutely aware of the underlying risks of asset price inflation, not least due to the lessons learned from Japan's experience in the 1980s (Box 3). The government has, therefore, deployed a range of regulatory tools to contain unwarranted inflation in asset markets. These have included increases in transaction taxes, stricter regulatory controls on lending (including lower loan-to-value ratios for second or third homes), and increases in mortgage interest rates for second or third homes. Staff argued that, while recent measures are treating the underlying symptoms, they have not tackled the fundamental causes of property price inflation. These are inextricably linked to a low cost of capital, prospects for capital appreciation (linked to urbanization and broader economic growth), and a lack of alternative savings vehicles. The authorities indicated that the measures taken in April to lessen speculative activity in the real estate markets had been effective, lowering transaction volumes and leading to a leveling off in prices. In addition, the Real interest rates are well below the growth rate. government would expand its investments in low income housing in the coming years. They also pointed out that deposit rates in China were still well above those in many other industrial countries. Nevertheless, the government will evaluate the impact of these measures over time and further enhance them, as needed, to ensure stability in the housing market. They indicated that, while there is no timetable yet for the introduction of a property tax, research into the issue was underway. 
Figure 3. The Residential Real Estate Market

Main Message: A property price bubble is beginning to inflate in some urban areas but the authorities are acting preemptively to prevent a boom-bust cycle in asset prices from taking hold.

Real estate investment has returned to previous growth rates.

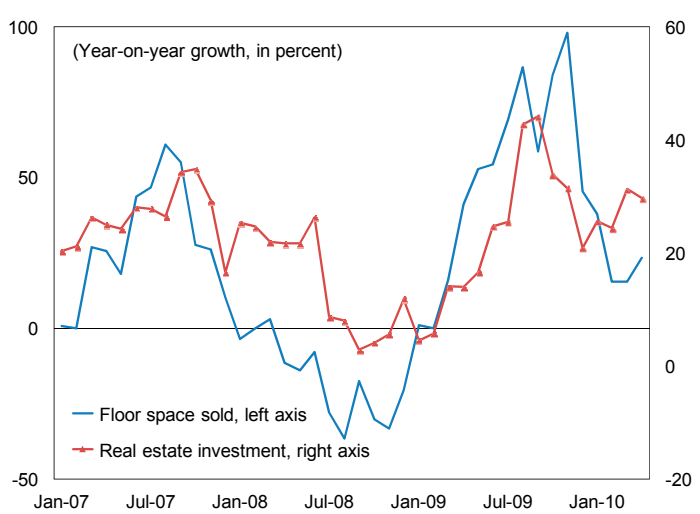

Prices are already high, as a ratio of household income, in some cities creating concerns about housing affordability.

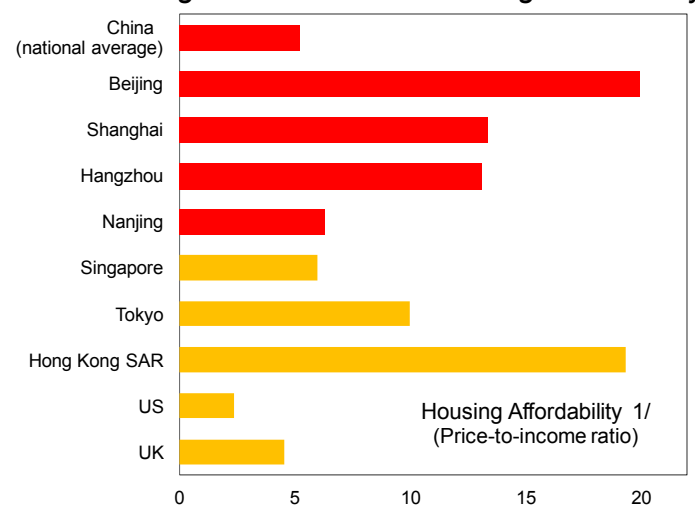

The government has responded with a graduated tightening of regulatory requirements.

\begin{tabular}{|l|l|}
\hline $\begin{array}{l}\text { March } \\
2010\end{array}$ & $\begin{array}{l}20 \text { percent capital ratio required for property } \\
\text { developers building affordable or mass } \\
\text { market housing }\end{array}$ \\
\hline April & $\begin{array}{l}\text { minimum downpayment for }>90 \text { square } \\
\text { meter homes increased to } 30 \text { percent } \\
\text { minimum downpayment of } 50 \text { percent } \\
\text { required for second homes } \\
\text { - }\end{array}$ \\
& $\begin{array}{l}\text { higher mortgage rates on second or third } \\
\text { homes } \\
\text { partgages for third homes discouraged, } \\
\text { pestrictions on bank loans and equity } \\
\text { issuance for property developers with idle } \\
\text { land or those found speculating in land } \\
\text { state enterprises, whose core business is not } \\
\text { in property, requested to exit the market }\end{array}$ \\
\hline
\end{tabular}

But the level of property price inflation, particularly in larger cities, has raised concerns of an asset price bubble

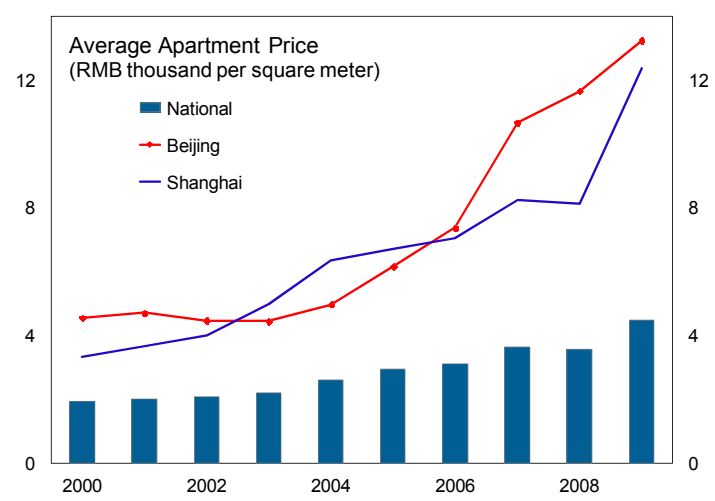

Lending to real estate has bounced back but remains a relatively small part of bank lending.

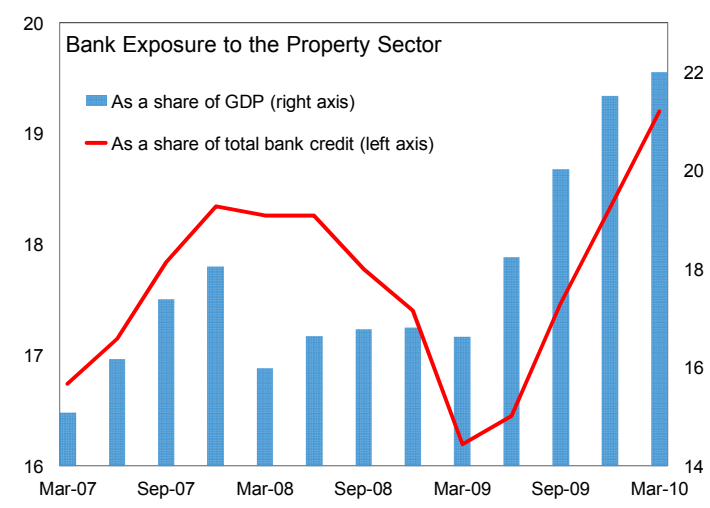

Precipitating a decline in transaction volumes and dampening expectations for further rapid price increases.

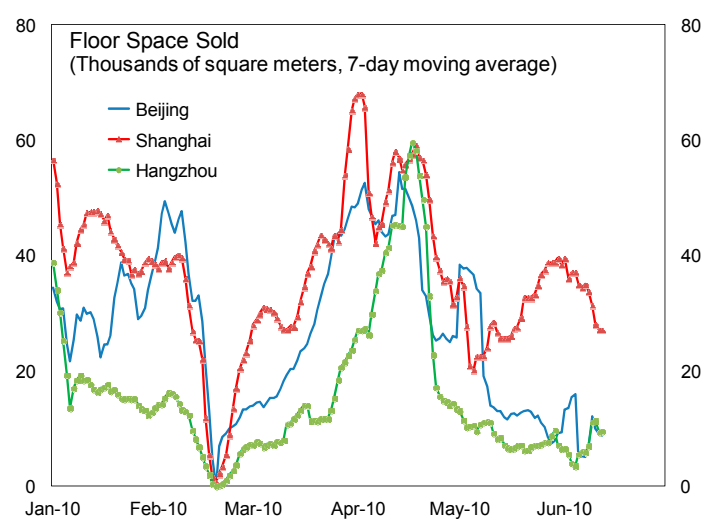

1/ For China, Tokyo, Hong Kong SAR, and Singapore the price of a 70 square meter apartment as a multiple of annual household disposable income. For the US and UK, median house price as a multiple of annual household personal disposable income.

Sources: Bloomberg; CEIC Data Company Ltd.; and staff estimates. 


\section{Box 2: China's Residential Real Estate Market $^{1}$}

An empirical model is used to link housing prices - in China and a set of comparator countries - to a set of key fundamentals. An estimated benchmark housing price is then derived. The fundamental explanatory variables include rents, real interest rates, property tax payments, the degree of mortgage tax deductibility, maintenance costs, a proxy for expected capital gains, and an additional risk premium between owning and renting a home.

Estimates indicate that, for China as a whole, the deviation between the current price and underlying fundamentals is relatively small. The same model does, however, show large deviations from fundamentals in those countries in the sample that were subsequently found to have had a significant property price bubble prior to the onset of the global financial crisis.

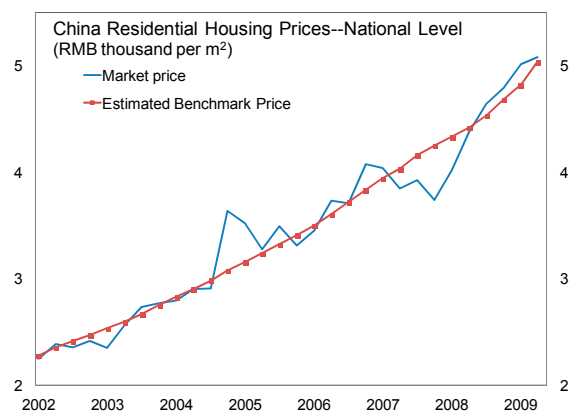

However, the picture differs greatly across China's cities. In particular, the deviation of housing prices from the estimated benchmark is larger in some, but not all, of the Tier-1 cities. Interestingly, despite rapid price inflation in Shanghai, the deviation of the current price from the benchmark is more modest. This is largely because rents in Shanghai have more closely tracked house price inflation than elsewhere in

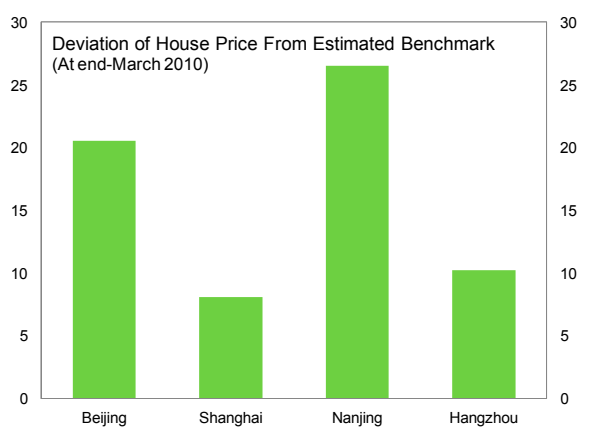
China.

\footnotetext{
${ }^{1}$ See A. Ahuja and N. Porter, “Are House Prices Rising too Fast in China?” IMF Working Paper (forthcoming).
} 


\section{Box 3: Key Lessons from Recent Japanese History ${ }^{1}$}

China's economy today faces the difficult task of shifting its sources of growth away from exports and investment and toward private consumption. This is a similar challenge to that which confronted Japan in the 1980s. During that period, Japan's growing share of the global export market inflamed protectionist sentiments, eventually resulting in the Plaza and Louvre accords. As part of these accords, Japan agreed to appreciate the yen, implement fiscal policies to support domestic demand, promote private sector development, and conduct monetary policy in a flexible manner with due attention to the exchange rate. Analysis of this history provides the following lessons:

- $\quad$ There are limits to export-oriented growth. At its peak, Japan occupied around 10 percent of global exports and, by the mid-1980s, was beginning to find it increasingly difficult to push its share in global markets higher.

- An incomplete package of measures will be unable to achieve sustained rebalancing. Shifting toward a

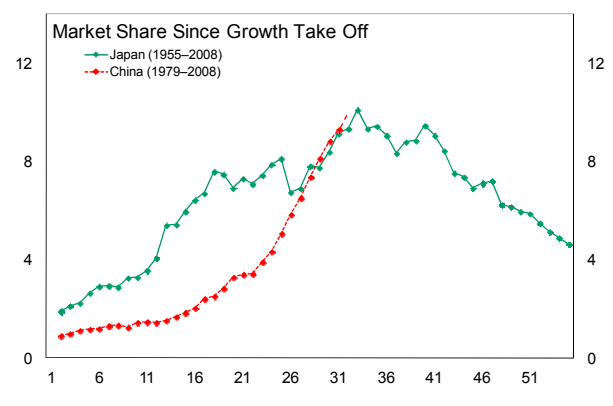
greater reliance on the service sector requires a real appreciation of the exchange rate, supportive macroeconomic policies, and structural reforms to develop nontradable sectors. Japan's experience shows that without all the components in place and working in concert the risk of incomplete rebalancing and economic stagnation is high.

- The growth and employment impact of exchange rate appreciation can be alleviated with supportive macroeconomic policies. The appreciation of the yen that followed the Plaza accord led to slower growth and higher unemployment. However, these trends were subsequently reversed by a looser monetary stance and supportive fiscal measures.

- However, such supportive macroeconomic policies, if maintained for too long, can inflate asset bubbles. Maintaining loose monetary policy for too long combined with incentives to boost consumer and mortgage credit fueled a rapid rise in equity and land prices in Japan. The subsequent protracted adjustment in goods and asset markets and the deleveraging in household, bank, and non-financial corporate balance sheets contributed to Japan's "lost decade" of deflation, public debt accumulation, and stagnation.

- Financial liberalization has to be carefully managed. Liberalizing interest rates in the context of a banking system with excess liquidity has the potential to lead to a significant decline in deposit rates, fueling asset price inflation. An early shift toward greater reliance on indirect monetary instruments can help to maintain control over monetary aggregates following liberalization but, even with this, the stance of monetary policy still needs to be correctly calibrated.

${ }^{1}$ See P. N’Diaye, "Lessons for China from Japan's Experience in the 1980s," IMF Working Paper (forthcoming). For a broader perspective on the lessons from episodes of current account surplus reversals see World Economic Outlook, April 2010, "Getting the Balance Right: Transitioning out of Sustained Current Account Surpluses.” 


\section{What are the Vulnerabilities in Local Governments' Fiscal Positions?}

16. Context. Despite legal restrictions prohibiting subnational borrowing, it has been common practice for a number of years for local governments to establish corporate vehicles (capitalized by transfers of money, land, equity, or other government assets), which are then used to borrow. In addition to their publicly provided capital, these financing platforms regularly receive implicit or explicit guarantees from the local government to underwrite their borrowing. In 2008-09, as restrictions on credit growth were removed and the central government actively encouraged infrastructure investment to offset the shock to external demand, local governments significantly increased their recourse to such vehicles.

17. Risks. Information on the activities of these entities (and their underlying financial condition) is sparse, making it exceedingly difficult to assess the risks they imply for the banking system. Indeed, officials indicated they were only now putting in place systems to identify and measure the level of recourse to these financing arrangements. Some part of the expansion in this quasi-fiscal lending will end up as nonperforming loans with negative implications for both local government finances, bank balance sheets, or, potentially, central government finances. The ongoing Financial Sector Assessment Program (FSAP) will carefully assess the underlying vulnerabilities associated with such lending.

18. Policies. It was generally agreed that many of the investments being made at the subnational level were needed and were in projects that would ultimately improve the livelihoods of the Chinese people. Lowering the potential risks from such lending, however, will need to involve better information in the operations of local government financing platforms; work is already underway within the government to collect such data. Officials underlined their commitment to more strictly enforce the existing prohibition on direct local government borrowing and the use of explicit (or implicit) local government guarantees. They particularly pointed to the recent instruction by the State Council, reaffirming that local governments cannot borrow directly or issue debt guarantees and, if they do, any such guarantees will be deemed invalid. To contain credit risks, the China Banking Regulatory Commission (CBRC) has instructed banks to reappraise all lending to local government vehicles and, if needed, return to the borrowers to request additional collateral to back such lending, particularly for those projects where the underlying cashflows are weak or insufficient. Staff argued that some consideration could also be given to formalizing local government financing (for example through establishing a municipal bond market), accompanied by appropriate prudential controls. Any such change, however, would need to weigh carefully the broader consequences for fiscal federal relations and fiscal stability going forward. In addition, staff indicated that the introduction of a property tax would benefit local government finances and lessen local governments' reliance on land sales as a source of revenue. 


\section{How has the Credit Expansion Affected the Banks?}

19. Context. The scale of the expansion in credit has been unprecedented. Experience, in both China and abroad, would suggest that this could soon be accompanied by a worsening in average credit quality. The government is conscious of this risk and has tightened prudential regulations by building up reserves (through higher provisioning for nonperforming loans), more stringent capital adequacy standards, placing limits on bank guarantees for corporate bonds, and tightening liquidity and concentration ratios. In addition, banks have been strongly encouraged to raise new capital and, indeed, many have done so in recent months.

Banking System Indicators (In percent) Liquid assets/liquid liabilities 1/ $\quad 41.1$ NPL (share of loans) 1/ 1.4 Provisioning (share of NPLs) 1/ 170.2 CAR 2/

Tier 1 Capital $2 /$

1/ March 2010.

2/ Share of risk-weighted assets, December 2009.

3/ December 2009

20. Implications. A detailed assessment of risks will be provided by the ongoing FSAP. At this point, the banking system looks well-placed to withstand a significant deterioration in credit quality. Profitability is solid, most banks meet the regulatory requirements of being well capitalized, large banks are subject to a capital surcharge, and provisioning levels are being increased. The authorities noted that, in addition to their proactive regulatory response, the loan rate floor and deposit rate ceiling - and the resulting loan-deposit rate marginwould also provide some protection to the banking system going forward. Nevertheless, they would continue to scrutinize carefully banks' risk management practices and adapt China's regulatory framework as international standards evolve.

\section{Where IS THE Chinese ECONOMY HeAding OVER A LONGER HoRizon?}

\section{A. Will the Decline in the Current Account Surplus Endure?}

21. Prospects. In the past two years, the current account surplus has almost halved as global demand collapsed and China's demand for commodities and capital goods imports picked up. Indeed, import volume growth has well outpaced export growth for more than a year and the current account surplus is still falling (Figure 4). However, as external demand recovers and the fiscal position moves back to budget balance (and assuming current policies and a constant real exchange rate) there is a potential for larger current account surpluses to reassert themselves (Box 4). The accumulation of net foreign assets will also put upward pressure on the current account through its impact on income flows, particularly as global interest rates return to more normal levels. The authorities disagreed with this assessment. Instead, they anticipate that the current account surplus will settle at about 4 percent of GDP over the medium term. Ongoing structural reforms, rising wages, and the recent appreciation of the currency will combine to boost consumption. At the same time, continued fast growth will shrink the current account surplus as a share of GDP. They underlined the important progress that had already been made in lowering the current account imbalance and expected that policies would continue to be calibrated to ensure that large surpluses do not return, 
recognizing that the high level of the trade surplus witnessed in 2007 was simply not sustainable.

\section{Box 4: Prospects for the Current Account Surplus}

A Time Series Approach. Staff simulations - using a Bayesian Vector Autoregression model (BVAR) estimated on quarterly data - suggest that the recent decline in the current account surplus may be partially reversed in the coming years. The model was fitted to historical data and used to forecast assuming:

- a steady fiscal consolidation in China;

- a recovery in the global economy along the path forecasted in the current World Economic Outlook;

- constant real exchange rates.

Under this out-of-sample simulation, beginning from end-2009, the current account surplus rises to around $8 \frac{1}{2}$ percent of GDP over a two-year horizon. Most of the impact is due to the pace of recovery in the global economy with little apparently attributable to the change in fiscal stance.

\section{A Structural Modeling Approach.}

Simulations using the Global Integrated Monetary and Fiscal model (GIMF) show that the combination of stronger global demand and a lower fiscal deficit will increase the current account surplus to around 8-9 percent of GDP. However, compared to the BVAR results, the simulations based on this calibrated global structural model indicate a much larger impact of fiscal consolidation but a more modest effect from stronger global output.
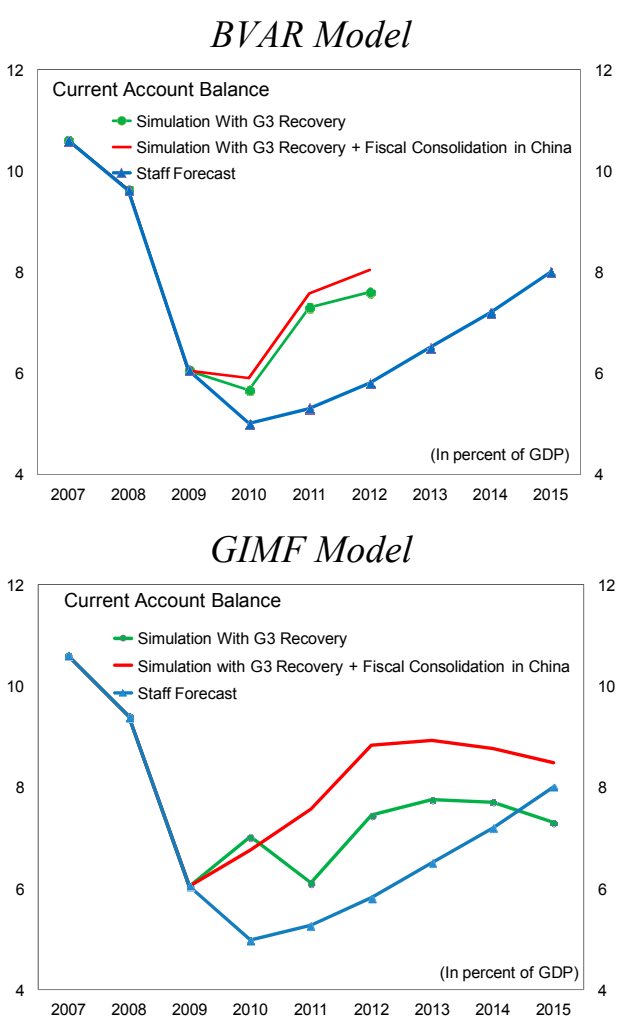

Staff's current account forecasts take these results as a guide but assume a more moderate increase in the current account than would be predicted by model simulations alone, using some degree of judgment to adjust for the impact of the policies put in place in 2009-10. 
Figure 4. The Decline in the Current Account Surplus

Main Message: While progress has been made in lessening imbalances, the recent downturn in the current account has the potential to be temporary and cyclical in nature.

The current account surplus has been almost cut in half over the past two years...

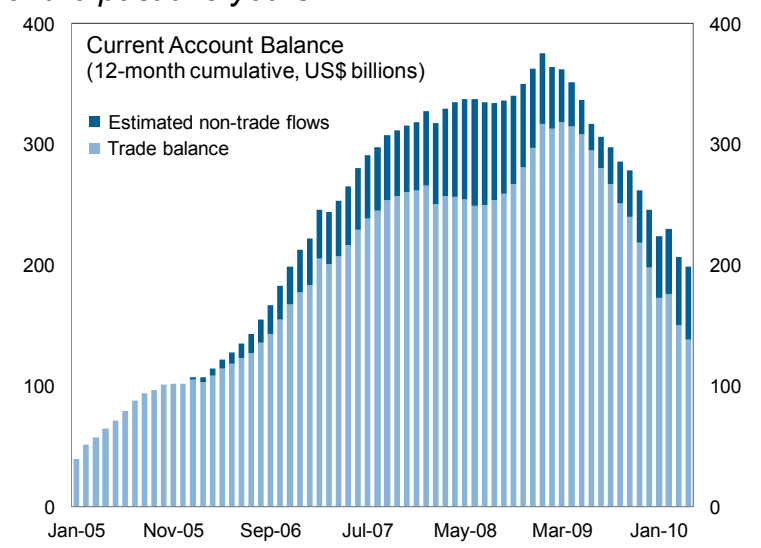

The terms of trade have also moved against China.

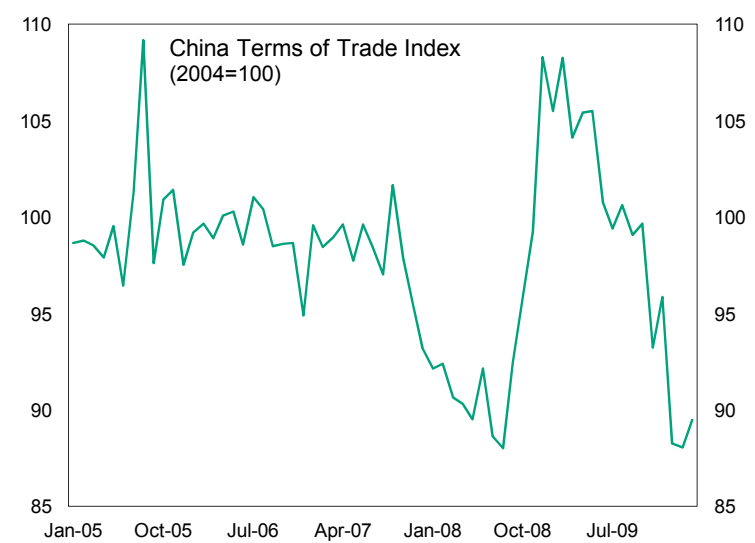

As the world economy recovers and China's fiscal stimulus is unwound...

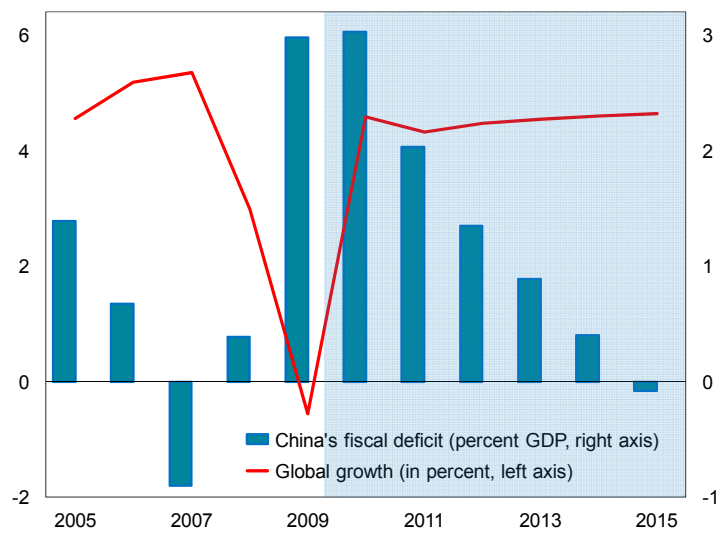

....reflecting a shift to fiscal deficits, stronger household consumption, and a surge in investment.

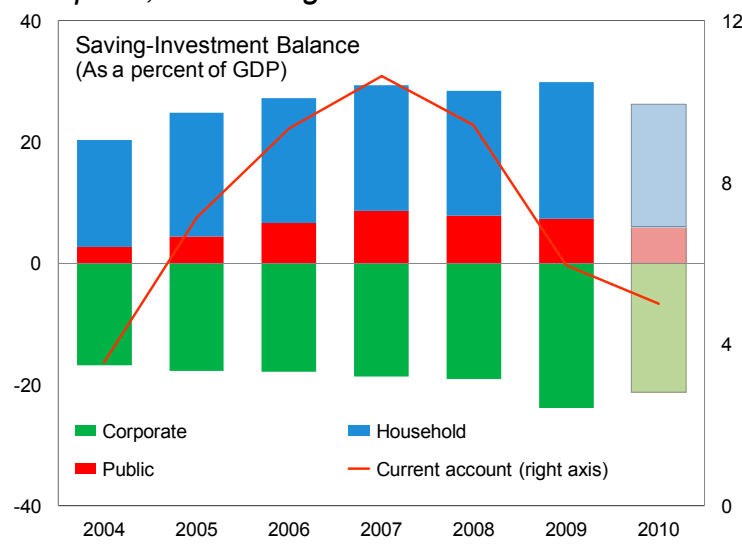

Nevertheless, even during this global downturn, China was able to continue building export market share.

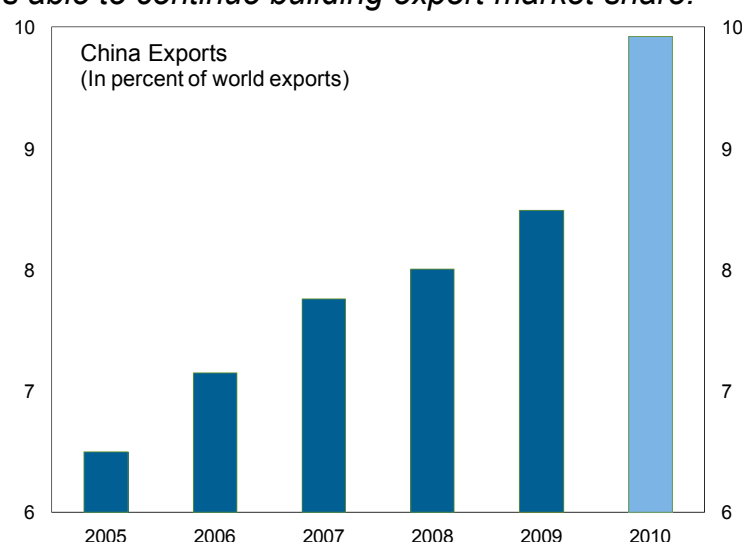

...staff see a potential for the current account surplus to reassert itself. The authorities, however, are confident the decline is a structural break that will be sustained.

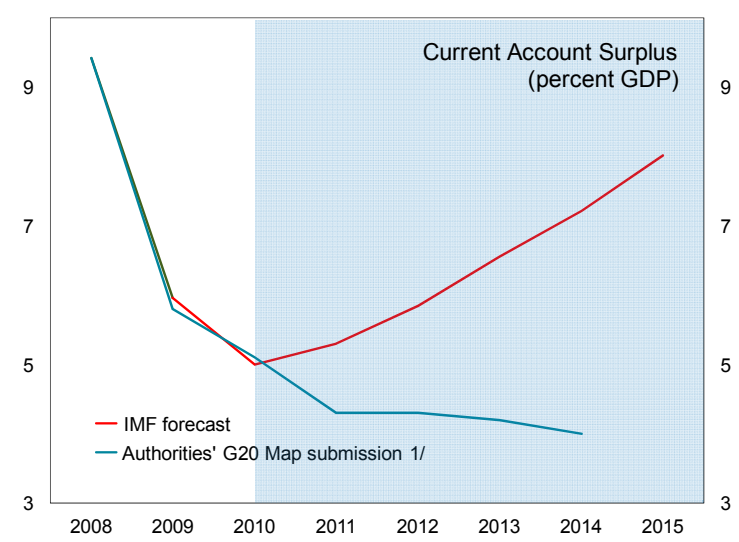

1/ Based on academic forecasts.

Sources: Bloomberg; CEIC Data Company Ltd.; and staff estimates. 
22. What does this imply for the exchange rate? Staff believe that the renminbi remains substantially below the level that is consistent with medium-term fundamentals. This assessment is based upon three broad arguments:

- $\quad$ The pace of accumulation of international reserves continues to be rapid. The authorities did not view this as compelling evidence of a meaningful undervaluation of the currency. In particular, they argued that the recent accumulation of international reserves was more a product of the unprecedented expansion of global liquidity, a result of monetary policy decisions in the large industrial economies.

- $\quad$ The current level of the real exchange rate is close to the level it was at in the late 1990s even though, in the interim, China has had significantly higher productivity than its trading partners. The authorities regarded it as arbitrary to judge the current level of the exchange rate by referencing a particular point in time when the currency may or may not have been in equilibrium. In particular, they noted that the currency was currently more than 50 percent stronger than when the exchange rate was unified in 1994 and 22 percent more appreciated than at its recent low point in 2005. They also made the broader point that the real exchange rate had been very flexible over the past decade, moving significantly in both directions. Staff agreed that comparison to any one point in time could indeed be deceptive. However, the real exchange rate was now back to the average level of 1999-2003, a period when there did not appear to be any decisive imbalance in the external accounts. In the interim, cumulative

The real exchange rate is now around the level of a decade ago.

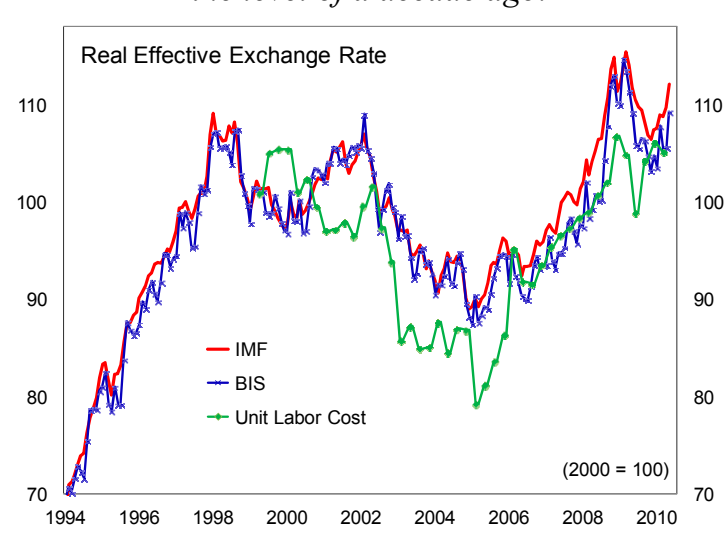

Productivity Differentials (2000-08)

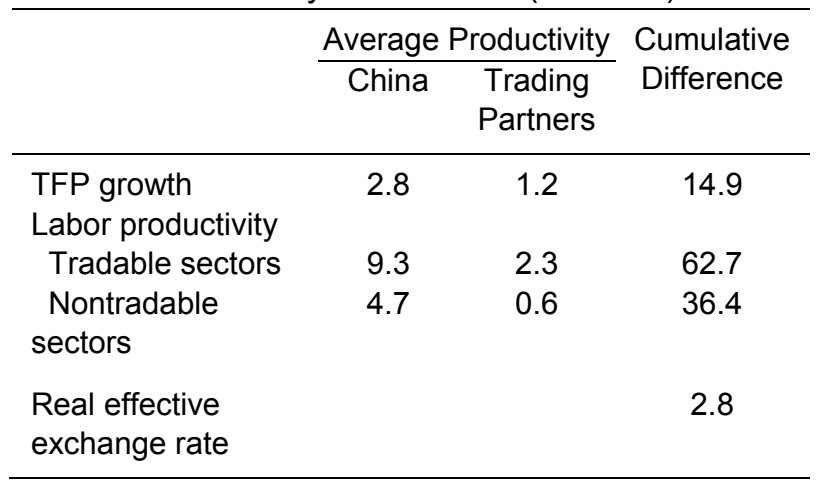
productivity differentials had been substantial.

- China's current account is set to return to a position of sizable surplus in the coming years. The authorities refuted this view, indicating that the reforms put in place over the past several years - including the appreciation of the real exchange rate, improvements in health, education, and pension systems, and others - are already resulting in a structural change in saving and investment behavior in China. They viewed the level of the renminbi right now as much closer to equilibrium than at any time before. In addition, they argued that China was at a stage of development where, going forward, the share of imports in domestic demand was likely to become an increasingly 
important factor. In addition, the trend processes of urbanization, demographic change, and rural reform will all work to lower the current account surplus. Therefore, the authorities believed that the current account surplus would continue to decline modestly in the coming months, leveling off at around 4 percent of GDP by end-2010, a level that was regarded as appropriate for China. If this forecast proves accurate, the resulting undervaluation (as measured by standard methodologies) would be negligible.

\section{B. How can Recent Gains in Consumption Growth be Sustained?}

23. Context. The Chinese government has emphasized boosting consumption for more than a decade. During that period, China's consumption growth has indeed been among the strongest of any country (growing on average by more than 8 percent per year). Nevertheless, China has still seen a secular decline in its consumption-output ratio due to rising rates of precautionary saving and a rate of growth of household income that has not kept up with GDP. Last year saw the beginnings of a reversal of this trend and the challenge now will be to sustain and strengthen that dynamic.

Consumption is low as a share of GDP.

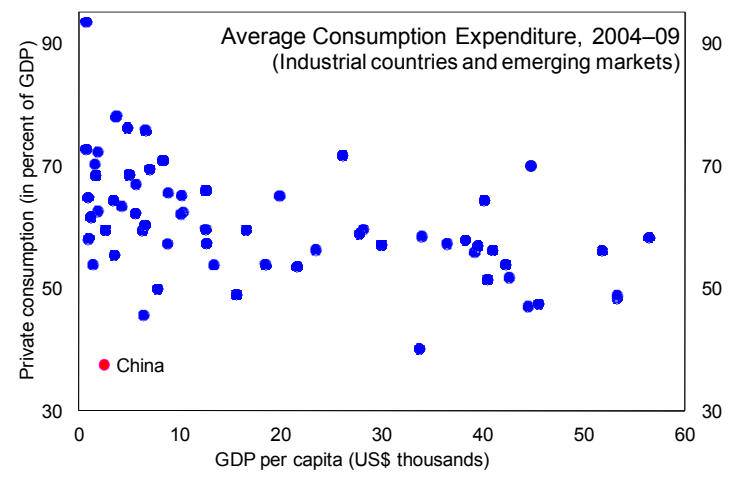

24. What does this mean for policies? To achieve a sustained rebalancing of the economy, continued progress will be needed in a range of areas:

- A stronger currency. An appreciation of the real exchange rate needs to be a key component of the government's medium-term strategy to rebalance toward higher private consumption. The current undervaluation is counterproductive and acts as a headwind to increasing private consumption. A stronger currency will help increase the purchasing power of households, raise the labor share of income, and reorient investment toward those sectors that serve the domestic market. There may be some negative short-term impact on growth and employment (Box 5) but, over time, job gains in the service sector should offset losses in tradable goods industries. The authorities noted that significant progress had already been made in strengthening the currency since 2005 . They believe that the structural changes that are taking place and the continued implementation of the reforms aimed at transforming the growth model point to a permanent shift from external to domestic demand. 


\section{Box 5: The Inter-Provincial Impact of Exchange Rate Changes ${ }^{1}$}

Panel data on Chinese provinces was used to examine the impact of exchange rate changes. The database provides for considerable cross-provincial economic diversity in growth, the movement in the real exchange rate (due to cross-province inflation differentials), and in structural factors. This heterogeneity allows for an examination of the different effects of currency movements across regions but also provides useful information on the impact on growth and employment for the economy as a whole.

- An appreciation of the currency in real effective terms has an impact on growth. In particular, a 5 percent appreciation of the exchange rate shaves a cumulative 1 percentage point off of headline growth. The effect lasts for around 2-3 years and then tapers off over time. Those provinces that have had a higher degree of appreciation, all else being equal, have seen slightly lower growth outturns.

- $\quad$ There are considerable geographical disparities in growth responses to a movement in the real exchange rate. For example, Western provinces are much less affected by movements in the exchange rate than the coastal provinces. This, in part, reflects a relatively lower dependence on
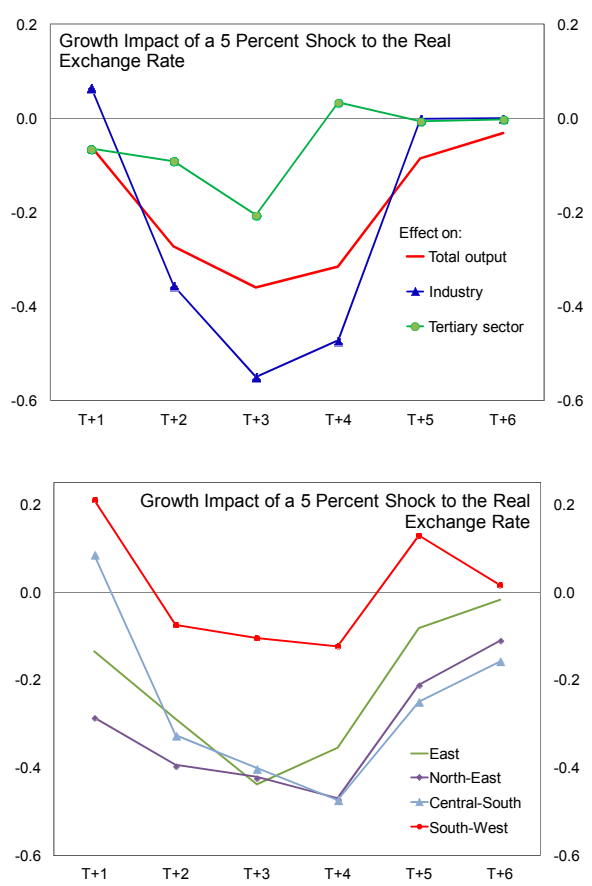
tradables in the Western provinces than elsewhere. More generally, across provinces, those with a large service sector or greater labor market flexibility appears to be less affected by currency appreciation.

- A real appreciation also effects employment; a 5 percent appreciation lowers employment growth by around $3 / 4$ percent.

- The bulk of the adjustment to exchange rate changes is borne by primary and manufacturing industries; there is a relatively little impact on the service sector.

- Not surprisingly, a stronger external environment can help offset the growth impact of movements in the currency.

\footnotetext{
${ }^{1}$ See R. Duttagupta, “Are China's Provinces Ready for a Stronger Currency,” IMF Working Paper (forthcoming). Similar work can be found in R. Chen and M. Dao, "The Real Exchange Rate and Employment in China," IMF Working Paper (forthcoming).
} 
- $\quad$ Financial liberalization. Important progress has been made in recent years in developing a more market-based financial system in China. Many fixed income markets have been liberalized, including rates on interbank transactions, central bank paper, and repo instruments. In addition, a SHIBOR reference yield curve has been established and markets for corporate bills and bonds continue to expand. Nevertheless, China still uses certain non-market means in order to maintain macroeconomic stability and conduct monetary policy. These include regulated ceilings on deposit rates as well as direct limits on the quantity of new bank lending. This has led to a financial system where the cost of capital is relatively low, credit allocation is sometimes determined by non-price means, and market prices have the potential to become disconnected from underlying fundamentals. Gradually moving to a system where there is an even greater role for markets in the setting of interest rates and determining the pace of loan growth would yield a more efficient allocation of capital, create incentives to favor labor over capital in the means of production, raise household income, and lessen the underlying propensity for asset price bubbles. Doing so, however, would need to be accompanied by continued improvements in banks' risk management systems and strong supervision.

- $\quad$ Financial development. There was broad agreement that continued development of equity markets and corporate bond markets will be an important ingredient to achieving a rebalanced economy. Considerable efforts have been made in this direction in recent years including the introduction of short selling and margin trading, the creation of traded index futures, and further expanding the markets for listing smaller corporations (with the creation of the Growth Enterprise Board last October). There was a common view that further steps could include the promotion of wider share ownership, a simplification of regulatory oversight in various markets, and mechanisms to increase liquidity in a range of markets. In addition, increased availability of a range of financial products_-including mutual funds, exchange traded funds, annuities and other insurance products - would be beneficial.

- $\quad$ Fiscal support for consumption. The authorities emphasized that they had already deployed multiple fiscal tools to boost consumption. Staff agreed that these measures had demonstrated significant effects on the economy and encouraged the authorities to go still further. For example, lowering the VAT rate and expanding its base would help increase the marginal incentives to consume. A similar effect could be achieved by reducing the burden of other consumption taxes or by further expanding the system of consumption incentives and subsidies.

- $\quad$ Raising household income. Staff argued that there was also significant scope to reduce the taxation of labor income. To do so would necessarily imply a reduction in social contributions (since personal income tax has only limited coverage). Staff pointed out that social contributions were high (in excess of 40 percent of base wages) and regressive. A lower level of contributions would boost household disposable income, lessen inequality, and foster job growth. However, this would also need to be accompanied by 
greater reliance on other revenue sources to ensure continued financing of social spending. Further increases in transfers to lower income groups and the unemployed could also be considered.

- Healthcare. China has achieved significant progress over the past several years with near universal coverage of health insurance in urban areas and significantly expanded coverage for rural residents. The government has increased its subsidies to cover health insurance premia, devoted significant resources to build hospitals and community health centers, and has plans already underway to expand the number of healthcare workers through training and other programs. Finally, the government has also introduced coverage for a core set of essential drugs. From 2009-11, through a budgetary investment of Y850 billion (around 21/4 percent of annual GDP), the government aims to achieve universal coverage of basic health services and to reduce the costs borne by patients. These efforts have been important but the authorities indicated there was still a very uneven quality of service delivery and funding across regions, particularly between rural and urban areas. They noted that lessening regional disparities in benefits and the quality of service would require further increases in fiscal resources, particularly to poorer regions. There was general agreement that, going forward, priorities should be to improve the healthcare system by increased investments in primary care and community health facilities , continuing to pursue universal healthcare coverage (particularly of rural and migrant workers), and reducing out-ofpocket expenses through higher reimbursement rates. Other goals were to reduce the medical system's heavy reliance on revenue from drug sales and user fees including by lowering the costs of essential drugs. Staff also advocated an expansion of benefits to cover catastrophic and chronic illness.

- Pensions. In 2009 the government launched its plan to introduce a new rural pension scheme, financed by the local and central government, and began pilots in 10 percent of rural counties. By end-2010 it is expected that 23 percent of rural counties will be covered with universal coverage by 2020 . For workers in urban areas, valuable efforts have also been made to increase the regional pooling of pension funds, unify key policy parameters at the provincial level, and increase the portability of urban pensions. Nonetheless, the pension system remains fragmented with multiple occupational systems that overlay the national rural and urban pension systems. This complexity will prove to be a constraint to a more dynamic labor market. The authorities agreed that reforms would need to focus on continuing to expand coverage of the new rural pension scheme and urban workers' basic pension system, increasing the uniformity of pension policies, and putting in place an effective mechanism for interprovincial transfers to facilitate increased portability. Staff indicated that it would also be important to realize (and deal with) the legacy costs from the current pension system and move toward greater pooling of risks at the national level.

- Education. Despite a relatively low level of public spending on education, China has achieved near universal enrollment and full public funding up to junior secondary 
education. Staff argued that the next steps could focus on ensuring universal publicly funded education up to the senior secondary school level and improving the quality of and access to education (particularly in poorer areas and to children of migrant workers).

- Urbanization. In China, 18 million people migrate to urban areas each year. Urban areas have less than one-half the population but generate over $3 / 4$ of China's consumption. The process of urbanization creates a steadily expanding flow demand for housing, services, and higher productivity jobs. The Chinese government has recognized the tremendous promise that continued urbanization holds for rebalancing the economy, developing the service sector, and maintaining the strong productivity performance that has underpinned China's spectacular growth. The authorities indicated the challenge ahead will be to generate sufficient urban employment to meet the inflows of new workers, to provide affordable housing and public infrastructure in a range of areas (sanitation, transportation, and others), and to tackle the environmental and energy use hurdles associated with a greater urban population. They emphasized the need for careful urban planning and a balanced approach to prioritizing and investing in urban infrastructure. Staff argued for greater efforts to foster labor mobility, including through improvements to the household registration system. There was broad agreement that labor mobility would also be facilitated by greater portability of entitlements and increased national uniformity of social protection schemes.

- $\quad$ Tackling high corporate saving. Corporate savings in China are high. This has been a critical factor in the large current account surpluses of recent years. The reasons for this are multifarious. In part, they are linked to low costs for various factor inputs (including capital, energy, and pollution). This has particularly benefitted highly capital and energy intensive industries in tradable sectors. Market structure is also important with some firms enjoying oligopoly positions in domestic markets. For some smaller companies, uncertain access to future financing has created incentives for precautionary saving to ensure that the resources are on hand to fund profitable projects. Finally, corporations are not subject to the same contestability of ownership that is seen in other systems. This may lead firms to have less incentive to distribute profits in the form of dividends, resulting in higher corporate savings.
Corporate, household, and government savings have all risen.

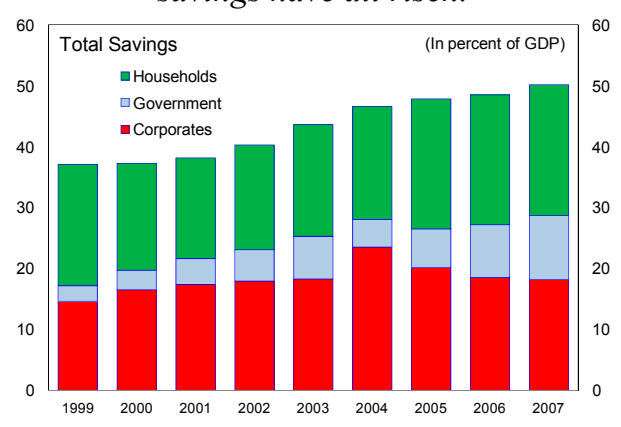

Average dividend yields in China are low despite high corporate profitability.

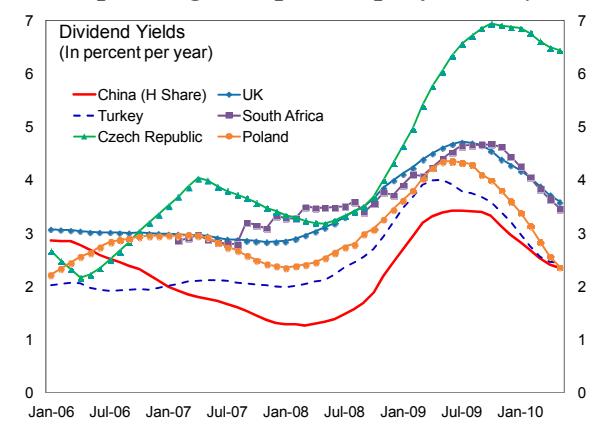


25. The authorities'view. The authorities expressed general agreement with the thrust of the structural agenda outlined by staff. They emphasized, and staff agreed, that remarkable changes had taken place in many of these areas over the past few years. Officials underlined the full commitment of the government to make China less reliant on exports and driven more by private consumption. They noted this was a dynamic reform process and certainly not all the reforms had yet been fully deployed; further measures were, nonetheless, being carefully studied. The authorities also noted that China's performance should be judged in an international context. They believed that China had moved at a much faster pace toward strong, sustained, and balanced growth than others in recent years, in part due to the difficult short-term economic and social situation in many of the industrial countries.

\section{STAFF APPRAISAL}

26. Growth. The government's policy response to the global financial crisis has been proactive, speedy, and resolute. Its success can be clearly seen in the robust outturn in 2009, where growth exceeded 9 percent despite an over 4 percent of GDP drag on the economy from net external demand. The recovery is well established and a transition from public stimulus to private sector-led growth is underway. Staff projects growth will reach into the double digits this year, decelerating modestly in 2011 as fiscal and monetary stimulus are wound down. These achievements further reinforce China's position as a central driver of global growth.

27. Inflation. At this point in the recovery, there is little evidence that the upswing in inflation is coming from either binding capacity constraints, rapid growth in broad monetary aggregates, or demand pressures. Barring an unforeseen supply shock to food prices, consumer price inflation should peak in mid-year and begin falling in the second half of 2010 .

28. Monetary policy. The authorities' target for broad money growth for this year balances well the need to provide continued support to the economy on the one hand and to safeguard the health of bank balance sheets on the other. To achieve the targeted withdrawal of monetary stimulus, benchmark interest rates could be moved higher, liquidity can be absorbed through greater issuance of central bank paper and repo operations, and reserve requirements could be further increased. A more flexible exchange rate will also serve to support this withdrawal of monetary stimulus. Over a longer horizon, the government should consider moving toward the full use of indirect instruments for monetary policy and the phase-out of direct limits on new lending.

29. Fiscal policy. The stimulus package initiated in 2008 has provided essential support to the economy. Fiscal stimulus from the state budget ought to be maintained over the near term but further reoriented, insofar as is possible, away from capital investment and toward measures to raise household income, lessen income inequality, improve the social safety net, and boost consumption. While such measures may not be as fast-acting or with as large a multiplier as infrastructure spending, they are likely to provide more enduring social and 
economic benefits, helping to facilitate a rebalancing toward private consumption. In 2011, presuming the current trajectory for the economy is maintained, fiscal stimulus could begin to be gradually phased out and spending on capital projects (both in the budget and through local government financing platforms) can be wound down.

30. The exchange rate. The central bank's recent decision to return to the managed floating regime that was in place prior to the global financial crisis is extremely welcome. This decision affords the central bank considerable flexibility to tighten monetary conditions through an appreciation of the exchange rate. Going forward, the central bank will need to avoid having movements in the real effective exchange rate determined by the relative strength or weakness of the U.S. dollar, particularly given the very different cyclical conditions in the two economies. In addition, unlike in 2005, there is now significantly more liquidity in the global financial system. As China begins to appreciate the renminbi, it will have to confront the prospect of a surge in inflows aiming to circumvent the existing capital control regime. Macroeconomic and prudential policies will need to be attentive to ensuring that such capital flows do not feed rapid price increases in key asset markets or undermine the steady progress made over the past several years to improve the health of the financial system.

\section{Handling near-term risks}

31. The global context. The principal near-term risk facing China arises from a renewed downturn in the global economy. If such downsides were realized, China has the flexibility and room to return to an expansionary fiscal stance to offset the shock to external demand. In doing so, a larger weight could be put on budgetary measures to boost private consumption rather than further increases in public infrastructure spending. Over time, medium-term reforms to rebalance the economy toward private consumption will reduce China's reliance on external demand and better insulate the economy from shocks in overseas markets.

32. The property sector. It is probably too early to say that, on a national level, property prices are significantly above fundamentals. However, prices in an increasing number of the larger cities have been rising rapidly and a property bubble is beginning to inflate. Unfettered, this dynamic risks leading to an acceleration of property price inflation followed by a crash in the real estate market. Such a path has been seen repeatedly in other countries. Therefore, the pragmatic deployment of a range of countervailing prudential measures has been fully warranted. Nonetheless, calibrating such a policy response is complicated and carries with it a risk of both over- and under-reaction. The government will have to carefully fine-tune these measures in order to avoid excessively driving down prices or curtailing real estate investment. Recent price increases are, however, a symptom of a deeper, structural problem. In spite of the government's efforts, the propensity for property price inflation and concerns about bubbles will persist. A lasting solution will need to include a combination of structurally higher real interest rates, the introduction of a meaningful property tax to raise the carrying costs of real estate, and broader financial market development to provide 
alternative destinations for China's high savings. A property tax would also serve to strengthen local governments' financial positions and lessen their reliance on land sales as a source of revenue.

33. Local government finances. The recent increase in the use of local government investment platforms to finance infrastructure and other projects has been extraordinary. Given the low levels of transparency for many of these operations, the heterogeneous nature of their activities, and the weak fiscal situation of many local governments, inevitably some share of the lending associated with these financing platforms will go bad. It is, however, exceedingly difficult to quantify the risks that such lending could imply for bank balance sheets. Greater transparency is needed. Going forward, all such entities should be required to publish annual, audited financial statements. It is also fully appropriate that the Ministry of Finance, together with the People's Bank of China and CBRC, are now working to build a comprehensive database to better understand these operations. Once available, that data could also be published.

34. Credit quality. Last year's rapid expansion in credit, over time, will likely translate into weaker credit quality and an eventual increase in nonperforming loans; the international history in this context is compelling. Recent efforts to tighten prudential requirements will provide important protection to the banking system. In addition, the apparent financial health of the principal banks should allow them to absorb losses associated with this increased lending. Nonetheless, the expected rise in nonperforming loans will still place strains on bank balance sheets in the coming years. These will need to be closely monitored, particularly for some of the smaller, regional banks.

\section{Rebalancing}

35. Current account. The recent decline in the current account surplus has been dramatic. However, international experience indicates that for reversals of current account surpluses to be sustained, there typically needs to be a combination of a real effective appreciation of the currency, macroeconomic policies to support demand, and in some cases, structural reforms to develop the nontradable sectors of the economy. Under currently announced policies and assuming a constant real exchange rate, there is a potential for significant current account surpluses to reappear over the medium term, albeit not of a scale that was seen in 2007.

36. A sustained rebalancing. To achieve and sustain the government's predicted decline in the current account surplus will be an exceptionally complicated exercise in macroeconomic engineering. At this point, the critical mass of policy reforms that will be needed to realize this goal is not yet fully in place. In addition to the commendable efforts already underway, a sustained decline in the current account surplus will require concerted action on multiple fronts.

37. A stronger currency. A stronger renminbi is needed and the recent reform of the exchange rate regime affords the flexibility necessary to undertake this appreciation. It is 
possible that shifting resources from the export sector to industries that are more geared toward domestic markets will take time and, in the interim, growth and employment could be moderately lower than would otherwise be the case. This is a valid concern. Nevertheless, given international experience and staff analysis, we are convinced that, over time, job gains, particularly in the service sector, will outweigh near-term losses and the benefits to the Chinese people from a stronger currency will far outweigh the costs.

38. Financial liberalization. Notwithstanding the significant progress made in financial market liberalization, China should work toward an eventual removal of ceilings on deposit rates, to make them more market-determined and responsive to forces of demand and supply. At the same time, the government should move toward a greater reliance on indirect instruments in exercising monetary control, giving up the use of direct limits on bank lending. Unwinding the complex system of controls that are currently in place will take time and will need to be carefully sequenced as well as closely supervised and regulated. It will be particularly critical that, as interest rates are liberalized, this does not translate into an unintended loosening of monetary conditions. Rather, such reforms should be designed carefully in order to lead to a structural increase in real interest rates.

39. Financial development. Moving to a fully market-based system of financial intermediation will need to be accompanied by the development of a broader array of financial markets and instruments. This would offer households alternate investment and insurance products, increase household capital income, and lessen the demand for physical assets - such as housing - as a store of value. Such reforms would support consumption, lower corporate saving, increase employment, improve the allocation of capital, and lessen the likelihood of asset price bubbles. The ongoing FSAP will provide valuable input in articulating a clear roadmap for financial development in the coming years. That assessment will form an integral part of next year's Article IV consultation.

40. Fiscal support for consumption. The recent efforts to provide budgetary incentives to raise household income, lower income inequality, and boost consumption have been effective. However, the underlying momentum in catalyzing consumption needs to be maintained and deepened. To do this, the government could examine ways to lower further the tax burden on both consumption and labor income and further increase transfers to lower income households and the unemployed. Such a reorientation of fiscal policy would have to be designed within the broader context of ensuring a medium-term downward path for the fiscal deficit. As such, supporting consumption and boosting household income may require offsetting actions to raise other revenue sources (for example, from property taxes) and reduce other spending items.

41. Social safety nets. Over the past year, there has been admirable progress in building a more effective system of social insurance in China. Recent efforts to expand pension coverage to rural residents, improve the portability of urban pensions, and increase the quality and availability of health care will be indispensable in lessening household-specific 
risk and lowering the motivation for precautionary saving. Further steps could include greater access to high quality health care, particularly for rural residents and migrant workers, an expansion of benefits to cover catastrophic and chronic illness, and a reduction in out-ofpocket expenses for the insured. The government is also right to continue to move toward its goals of universal coverage of the basic pension, with a particular focus on covering rural residents and migrant workers, greater pooling at the national level, and full portability of pension benefits.

42. Urbanization. Fully capitalizing on the potential that urbanization holds will require a range of reforms. Over time, there will need to be a removal of various barriers to labor mobility, an improvement in the household registration system, continued rural land reform, measures to ensure uniform access to education and social protection for all urban residents (particularly migrant workers), and a reexamination of the intergovernmental fiscal system. Effective urbanization also means that the government will need to continue to seek out ways to ensure the availability of affordable housing in urban areas and to prioritize large investments in a range of urban infrastructure. Finally, greater urbanization will bring with it an increased demand for a range of services that has the potential to generate a significant number of jobs. To ensure that a service economy fully develops, barriers to competition and private participation in service industries will need to be sought out and removed.

43. Lessening corporate savings. Realigning relative prices of various factor inputs through increases in the cost of capital, land, electricity, gas, water, and pollution will lower corporate savings, particularly in capital and energy intensive industries. This would be fully in line with the government's own priorities to conserve energy, reduce emissions, and protect the environment. There has already been progress in this direction as domestic petroleum product prices are now more closely linked to global price movements. However, recent moves to reduce VAT rebates to select industries are distortionary and counterproductive. Instead, it would be better for the VAT to be zero-rated for all exports with the objectives of dissuading energy intensive and polluting industries achieved through other means. The government may also wish to consider expanding its program of having state owned enterprises pay dividends to the budget, and ensure that these dividends are used to finance general budget spending (rather than being recycled back into the corporate sector through various means). Efforts ought to be made to ensure there is sufficient competition in domestic markets to avoid companies leveraging their oligopoly positions to generate excess rents. Finally, increasing households' stake in the corporate sector through wider share ownership — both directly and via institutional investors - will allow high corporate saving to translate into increased household wealth. This, in turn, will facilitate higher household consumption.

44. Conclusion. The government's macroeconomic policy response to the crisis has delivered very positive results and mitigated the impact of the global downturn on China's economy. China has also made significant progress in many of the policy areas that have been highlighted in the G-20 Mutual Assessment Process. In doing so, China is contributing 
greatly toward ensuring strong, sustained, and balanced global growth. The challenge now lies in calibrating the pace of exit from these crisis measures, particularly in the context of a very uncertain global environment. In addition, there is a broad structural agenda to be accomplished if China is to realize its own goal of making private consumption a central driving force behind growth in the coming years. In achieving that outcome, no policy tool should be left untapped. A stronger currency will be needed but should be viewed not in isolation but rather as a part of the broader package of measures described above.

45. It is proposed that the next Article IV consultation with China takes place on the standard 12-month cycle. 
Table 1. China: Selected Economic Indicators

\begin{tabular}{|c|c|c|c|c|c|c|c|}
\hline & 2005 & 2006 & 2007 & 2008 & 2009 & 2010 & 2011 \\
\hline & & & & & & \multicolumn{2}{|c|}{ Proj. } \\
\hline & \multicolumn{7}{|c|}{ (Annual percentage change, unless otherwise specified) } \\
\hline \multicolumn{8}{|l|}{ National accounts and employment } \\
\hline Real GDP & 11.3 & 12.7 & 14.2 & 9.6 & 9.1 & 10.5 & 9.6 \\
\hline Total domestic demand & 9.2 & 11.5 & 12.7 & 9.7 & 14.8 & 11.5 & 9.4 \\
\hline Consumption & 8.1 & 9.8 & 11.1 & 8.6 & 9.9 & 13.2 & 11.0 \\
\hline Investment & 10.6 & 13.6 & 14.7 & 11.0 & 20.4 & 9.7 & 7.6 \\
\hline Fixed & 11.9 & 12.8 & 13.4 & 9.7 & 24.6 & 10.1 & 7.9 \\
\hline Inventories 1/ & -0.3 & 0.6 & 0.8 & 0.8 & -1.0 & 0.0 & 0.0 \\
\hline Net exports 1/ & 2.6 & 2.0 & 2.5 & 0.8 & -4.3 & -0.5 & 0.6 \\
\hline \multicolumn{8}{|l|}{ Consumer prices } \\
\hline End of period & 1.4 & 2.0 & 6.6 & 2.5 & 0.7 & 3.5 & 2.7 \\
\hline Average & 1.8 & 1.5 & 4.8 & 5.9 & -0.7 & 3.5 & 2.7 \\
\hline \multirow[t]{2}{*}{ Unemployment rate (annual average } & 4.2 & 4.1 & 4.0 & 4.2 & 4.3 & 4.1 & 4.0 \\
\hline & \multicolumn{7}{|c|}{ (In percent of GDP) } \\
\hline \multicolumn{8}{|l|}{ External debt and balance of payments } \\
\hline Current account & 7.1 & 9.3 & 10.6 & 9.6 & 6.0 & 5.0 & 5.3 \\
\hline Trade balance & 5.9 & 8.0 & 9.0 & 8.0 & 5.0 & 4.0 & 4.5 \\
\hline Exports of goods & 33.8 & 35.7 & 34.9 & 31.7 & 24.1 & 30.3 & 32.9 \\
\hline Imports of goods & 27.8 & 27.7 & 25.9 & 23.8 & 19.1 & 26.3 & 28.5 \\
\hline Gross external debt & 13.1 & 12.5 & 11.1 & 8.6 & 8.6 & 8.9 & 8.7 \\
\hline \multicolumn{8}{|l|}{ Saving and investment } \\
\hline Gross domestic investment & 42.1 & 43.0 & 41.7 & 44.0 & 47.7 & 50.0 & 49.2 \\
\hline National saving & 49.2 & 52.3 & 52.4 & 53.7 & 53.6 & 55.0 & 54.5 \\
\hline Government & 6.3 & 8.7 & 10.5 & 9.9 & 9.9 & 8.8 & 9.1 \\
\hline Non-Government & 42.9 & 43.6 & 41.9 & 43.8 & 43.7 & 46.2 & 45.5 \\
\hline \multicolumn{8}{|l|}{ Public sector finance } \\
\hline General government gross debt & 17.6 & 16.5 & 19.8 & 16.8 & 18.6 & 20.1 & 19.9 \\
\hline \multirow{2}{*}{ General government balance } & -1.4 & -0.7 & 0.9 & -0.4 & -3.0 & -3.0 & -2.0 \\
\hline & \multicolumn{7}{|c|}{ (Annual percentage change) } \\
\hline Real effective exchange rate & -0.3 & 2.2 & 5.0 & 8.5 & 2.7 & $\ldots$ & \\
\hline
\end{tabular}

Sources: CEIC Data Co., Ltd.; and staff estimates and projections.

$1 /$ Contribution to annual growth in percent. 
Table 2. China: Balance of Payments

(In billions of U.S. dollars, unless otherwise noted)

\begin{tabular}{|c|c|c|c|c|c|c|c|}
\hline \multirow[b]{3}{*}{ Current account balance } & \multirow{3}{*}{$\begin{array}{r}2005 \\
160.8\end{array}$} & \multirow{3}{*}{$\begin{array}{r}2006 \\
253.3\end{array}$} & \multirow{3}{*}{$\begin{array}{r}2007 \\
371.8\end{array}$} & \multirow{3}{*}{$\begin{array}{r}2008 \\
436.1\end{array}$} & \multirow{3}{*}{$\begin{array}{r}2009 \\
297.1\end{array}$} & 2010 & 2011 \\
\hline & & & & & & \multicolumn{2}{|c|}{ Proj. } \\
\hline & & & & & & 265.8 & 313.1 \\
\hline Trade balance & 134.2 & 217.7 & 315.4 & 360.7 & 249.5 & 211.7 & 265.6 \\
\hline Exports & 762.5 & 969.7 & $1,220.0$ & $1,434.6$ & $1,203.8$ & $1,610.4$ & $1,947.7$ \\
\hline Imports (BOP basis) & 628.3 & 751.9 & 904.6 & $1,073.9$ & 954.3 & $1,398.8$ & $1,682.1$ \\
\hline Services & -9.4 & -8.8 & -7.9 & -11.8 & -29.4 & -56.5 & -66.7 \\
\hline Income & 10.6 & 15.2 & 25.7 & 41.4 & 43.3 & 54.3 & 51.6 \\
\hline Current transfers & 25.4 & 29.2 & 38.7 & 45.8 & 33.7 & 56.4 & 62.7 \\
\hline Capital and financial account balance & 63.0 & 6.7 & 73.5 & 19.0 & 144.9 & 45.1 & -20.2 \\
\hline Capital account & 4.1 & 4.0 & 3.1 & 3.1 & 4.0 & 3.7 & 3.7 \\
\hline Financial account & 58.9 & 2.6 & 70.4 & 15.9 & 140.9 & 41.5 & -23.8 \\
\hline Net foreign direct investment & 67.8 & 56.9 & 121.4 & 94.3 & 34.3 & 12.7 & -2.0 \\
\hline Inward investment (net) & 79.1 & 78.1 & 138.4 & 147.8 & 78.2 & 66.5 & 59.8 \\
\hline Abroad & -11.3 & -21.2 & -17.0 & -53.5 & -43.9 & -53.7 & -61.8 \\
\hline Portfolio investment & -4.9 & -67.6 & 18.7 & 42.7 & 38.7 & -11.4 & -11.4 \\
\hline Assets & -26.2 & -110.4 & -2.3 & 32.7 & 9.9 & -20.1 & -20.1 \\
\hline Liabilities & 21.2 & 42.9 & 21.0 & 9.9 & 28.8 & 8.7 & 8.7 \\
\hline Other investment & -4.0 & 13.3 & -69.7 & -121.1 & 67.9 & 40.2 & -10.4 \\
\hline Assets $1 /$ & -48.9 & -31.9 & -151.5 & -106.1 & 9.4 & 4.7 & -45.9 \\
\hline Liabilities & 44.9 & 45.1 & 81.8 & -15.0 & 58.5 & 35.5 & 35.5 \\
\hline Errors and omissions $2 /$ & 26.9 & 24.8 & 15.4 & 24.5 & -43.5 & 0.0 & 0.0 \\
\hline Overall balance & 250.6 & 284.8 & 460.7 & 479.5 & 398.5 & 311.0 & 293.0 \\
\hline Reserve assets & -250.6 & -284.8 & -460.7 & -479.5 & -398.5 & -311.0 & -293.0 \\
\hline \multicolumn{8}{|l|}{ Memorandum items: } \\
\hline Current account, as percent of GDP & 7.1 & 9.3 & 10.6 & 9.6 & 6.0 & 5.0 & 5.3 \\
\hline Export growth (value terms) & 28.5 & 27.2 & 25.8 & 17.6 & -16.1 & 33.8 & 20.9 \\
\hline Import growth (value terms) & 17.6 & 19.7 & 20.3 & 18.7 & -11.1 & 46.6 & 20.3 \\
\hline FDI (inward), as a percent of GDP & 3.5 & 2.9 & 4.0 & 3.3 & 1.6 & 1.3 & 1.0 \\
\hline External debt $3 /$ & 296.6 & 338.6 & 389.2 & 390.2 & 428.7 & 472.7 & 516.8 \\
\hline As a percent of GDP & 13.1 & 12.5 & 11.1 & 8.6 & 8.6 & 8.9 & 8.7 \\
\hline Short-term external debt (remaining maturity) $3 /$ & 171.6 & 199.2 & 235.7 & 226.3 & 259.3 & 291.2 & 323.2 \\
\hline Gross reserves 4/ & 825.6 & $1,072.6$ & $1,534.4$ & $1,953.3$ & $2,425.9$ & $2,736.8$ & $3,029.8$ \\
\hline As a percent of ST debt by remaining maturity & 481.0 & 538.4 & 651.0 & 863.2 & 935.7 & 939.8 & 937.5 \\
\hline Real effective exchange rate $(1990=100)$ & 92.4 & 94.5 & 99.2 & 107.5 & 110.4 & $\ldots$ & $\ldots$ \\
\hline Net international investment position & 407.7 & 640.2 & $1,188.1$ & $1,493.8$ & $1,821.9$ & $\ldots$ & $\ldots$ \\
\hline In percent of GDP & 18.1 & 23.6 & 34.0 & 33.0 & 36.5 & & \\
\hline Nominal GDP & $2,256.9$ & $2,712.9$ & $3,494.2$ & $4,520.0$ & $4,984.7$ & $5,317.6$ & $5,911.2$ \\
\hline
\end{tabular}

Sources: CEIC Data Co., Ltd.; and IMF staff estimates.

1/ 2005 include bank capitalization and foreign exchange swap, estimated at US\$28.8 billion.

2/ Includes counterpart transaction to valuation changes.

3/ Data provided by the Chinese authorities unless otherwise indicated.

4/ Includes gold. 
Table 3. China: Indicators of External Vulnerability

\begin{tabular}{|c|c|c|c|c|c|c|c|}
\hline & 2003 & 2004 & 2005 & 2006 & 2007 & 2008 & 2009 \\
\hline \multicolumn{8}{|l|}{ Monetary and financial indicators } \\
\hline General government debt (official data; in percent of GDP) & 19.2 & 18.5 & 17.6 & 16.2 & 19.6 & 17.0 & 17.7 \\
\hline Broad money (M2: annual percentage change) & 19.6 & 14.9 & 16.3 & 17.0 & 16.7 & 17.8 & 27.6 \\
\hline Foreign currency deposits to broad money (percent) & 5.6 & 5.0 & 4.4 & 3.6 & 2.9 & 2.6 & 2.4 \\
\hline Credit (annual percentage change) & 21.1 & 14.5 & 13.0 & 15.1 & 16.1 & 18.7 & 31.7 \\
\hline Foreign currency loans to credit to the economy (in percent) & 5.2 & 5.0 & 4.9 & 4.5 & 4.7 & 4.4 & 5.2 \\
\hline Stock exchange index (end-of-period, December 19, $1990=100) 1 /$ & $1,569.1$ & $1,330.2$ & $1,220.9$ & $2,815.1$ & $5,521.5$ & $1,911.8$ & $3,437.5$ \\
\hline Stock exchange capitalization (percent of GDP) & 31.4 & 23.4 & 24.5 & 48.9 & 130.2 & 46.0 & 81.2 \\
\hline Number of listed companies (A-share) & $1,261.0$ & $1,349.0$ & $1,355.0$ & $1,398.0$ & $1,507.0$ & $1,581.0$ & $1,678.0$ \\
\hline \multicolumn{8}{|l|}{ Balance of payments indicators } \\
\hline Exports (annual percentage change, U.S. dollars) & 34.6 & 35.4 & 28.5 & 27.2 & 25.8 & 17.6 & -16.1 \\
\hline Imports (annual percentage change, U.S. dollars) & -39.8 & -35.8 & -17.6 & -19.7 & -20.3 & -18.7 & 11.1 \\
\hline Current account balance (percent of GDP) & 2.8 & 3.6 & 7.1 & 9.3 & 10.6 & 9.6 & 6.0 \\
\hline Capital and financial account balance (percent of GDP) & 3.2 & 5.7 & 2.8 & 0.2 & 2.1 & 0.4 & 2.9 \\
\hline Of which: gross foreign direct investment inflows & 2.9 & 2.8 & 3.5 & 2.9 & 4.0 & 3.3 & 1.6 \\
\hline Unidentified capital flows $2 /$ & $\ldots$ & $\ldots$ & $\ldots$ & $\ldots$ & $\ldots$ & $\ldots$ & $\ldots$ \\
\hline \multicolumn{8}{|l|}{ Reserve indicators } \\
\hline Gross reserves (billions of U.S. dollars) 3/ & 412.2 & 618.6 & 825.6 & $1,072.6$ & $1,534.4$ & $1,953.3$ & $2,425.9$ \\
\hline Gross reserves to imports of GNFS (months) & 8.2 & 10.4 & 11.6 & 12.4 & 14.9 & 21.1 & 17.9 \\
\hline Gross reserves to broad money (M2) (percent) & 15.4 & 20.1 & 22.9 & 24.7 & 28.9 & 28.6 & 27.3 \\
\hline Gross reserves to short-term external debt by remaining maturity (percent) & 447.6 & 502.1 & 528.7 & 584.1 & 697.2 & 926.7 & 935.7 \\
\hline \multicolumn{8}{|l|}{ External debt and balance sheet indicators } \\
\hline Total external debt (percent of GDP) & 13.4 & 13.6 & 13.1 & 12.5 & 11.1 & 8.6 & 8.6 \\
\hline Total external debt (billions of U.S. dollars) $2 /$ & 219.4 & 263.0 & 296.6 & 338.6 & 389.2 & 390.2 & 428.7 \\
\hline Of which: public and publicly guaranteed debt $4 /$ & 52.8 & 33.6 & 33.0 & 34.4 & 34.9 & 33.3 & 36.9 \\
\hline Banking sector debt & 58.6 & 97.6 & 101.9 & 120.0 & 126.6 & 126.3 & 132.4 \\
\hline Short-term external debt by original maturity (billions of U.S. dollars) & 102.8 & 138.7 & 171.6 & 199.2 & 235.7 & 226.3 & 259.3 \\
\hline Net foreign assets of banking sector (billions of U.S. dollars) & 85.5 & 108.2 & 161.4 & 205.2 & 190.1 & 251.0 & 204.5 \\
\hline Total debt to exports of GNFS (percent) & 43.0 & 37.7 & 33.6 & 30.4 & 27.8 & 23.7 & 32.1 \\
\hline Total debt service to exports of GNFS (percent) $5 /$ & 17.0 & 19.6 & 19.3 & 17.8 & 16.8 & 13.7 & 19.8 \\
\hline Of which: Interest payments to exports of GNFS (percent) 5/ & 1.1 & 0.8 & 0.6 & 0.5 & 0.4 & 0.3 & 0.4 \\
\hline Bond spread (EMBI China, end of period, basis points) & 58.0 & 57.0 & 68.0 & 51.0 & 120.0 & 228.0 & 64.0 \\
\hline \multicolumn{8}{|l|}{ Foreign-currency sovereign bond ratings } \\
\hline Moody's & A2 & A2 & A2 & A2 & A1 & A1 & A1 \\
\hline Standard and Poor's & BBB & $\mathrm{BBB}+$ & A- & A & A & A & A \\
\hline \multicolumn{8}{|l|}{ Memorandum items: } \\
\hline International investment position & & 276.4 & 407.7 & 640.2 & $1,188.1$ & $1,493.8$ & $1,821.9$ \\
\hline Nominal GDP (billions of U.S. dollars) & $1,641.0$ & $1,931.6$ & $2,256.9$ & $2,712.9$ & $3,494.2$ & $4,520.0$ & $4,984.7$ \\
\hline Exports of GNFS (billions of U.S. dollars) & 485.0 & 655.8 & 836.9 & $1,061.7$ & $1,342.2$ & $1,581.7$ & $1,333.3$ \\
\hline Real effective exchange rate (annual percentage change) & -6.6 & -2.7 & -0.3 & 2.2 & 5.0 & 8.5 & 2.7 \\
\hline
\end{tabular}

Sources: CEIC Data Co.; and IMF staff estimates.

1/ Shanghai Stock Exchange, A-share.

2/ Data provided by the Chinese authorities.

$3 /$ Includes gold.

4/ Debt of banking sector not included.

5/ IMF staff estimates. 
Table 4. China: Monetary Developments

\begin{tabular}{|c|c|c|c|c|c|c|c|c|}
\hline & \multirow[t]{2}{*}{2005} & \multirow[t]{2}{*}{2006} & \multirow[t]{2}{*}{2007} & \multirow[t]{2}{*}{2008} & \multirow[t]{2}{*}{2009} & \multicolumn{3}{|r|}{2010} \\
\hline & & & & & & Jan & Feb & Mar \\
\hline & \multicolumn{8}{|c|}{ (In billions of yuan) } \\
\hline Net foreign assets & $7,570.0$ & $10,086.5$ & $13,775.1$ & $17,897.1$ & $19,853.2$ & $19,866.2$ & $20,002.4$ & $20,228.0$ \\
\hline Net domestic assets & $22,268.0$ & $24,473.9$ & $26,569.1$ & $29,619.6$ & $40,769.3$ & $42,694.8$ & $43,604.8$ & $44,766.7$ \\
\hline Domestic credit $1 /$ & $24,837.0$ & $28,873.8$ & $33,965.9$ & $37,937.9$ & $49,588.9$ & $50,345.1$ & $51,244.9$ & $52,101.8$ \\
\hline Net credit to government & $1,520.0$ & $1,535.0$ & $2,820.8$ & $2,943.5$ & $3,229.0$ & $2,770.0$ & $2,922.6$ & $2,931.8$ \\
\hline Credit to non-government & $23,317.0$ & $27,338.7$ & $31,145.1$ & $34,994.4$ & $46,359.9$ & $47,575.1$ & $48,322.3$ & $49,169.9$ \\
\hline Other items, net $1 /$ & $-2,568.0$ & -693.8 & $1,128.1$ & 766.6 & 106.8 & $-1,132.6$ & $-1,208.1$ & $-1,598.2$ \\
\hline Broad money & $29,550.8$ & $34,560.4$ & $40,344.2$ & $47,516.7$ & $60,622.5$ & $62,560.9$ & $63,607.2$ & $64,994.7$ \\
\hline $\begin{array}{l}\text { Reserve money } \\
\text { Of which: }\end{array}$ & \multicolumn{7}{|c|}{ Of which: } & $15,003.3$ \\
\hline Required reserves & $2,060.0$ & $2,866.8$ & $5,409.5$ & $6,614.2$ & $8,519.7$ & $9,065.2$ & $9,491.3$ & $9,773.9$ \\
\hline Excess reserves & $1,799.1$ & $1,979.1$ & $1,432.1$ & $2,596.4$ & $1,723.2$ & 781.9 & 952.9 & 945.8 \\
\hline Net foreign assets of PBC & $6,269.8$ & $8,484.6$ & $12,387.8$ & $16,181.1$ & $18,457.1$ & $18,727.5$ & $18,881.2$ & $19,137.2$ \\
\hline Net domestic assets of PBC & 164.6 & -708.8 & $-2,233.3$ & $-3,258.9$ & $-4,058.6$ & $-4,445.5$ & $-3,618.2$ & $-4,133.9$ \\
\hline & \multicolumn{8}{|c|}{ (Twelve-month percentage change) } \\
\hline Net foreign assets $2 /$ & 8.0 & 8.5 & 10.7 & 10.2 & 4.1 & 3.9 & 3.8 & 3.8 \\
\hline Net domestic assets & 12.6 & 9.9 & 8.6 & 11.5 & 37.6 & 34.8 & 33.9 & 28.4 \\
\hline Domestic credit $3 /$ & 10.7 & 16.3 & 17.6 & 11.7 & 30.7 & 27.4 & 26.2 & 21.9 \\
\hline Of which: loans & 13.0 & 26.6 & 19.3 & 14.0 & 34.2 & 31.0 & 29.7 & 24.8 \\
\hline Other items, net $2 / 3 /$ & -3.2 & 6.3 & 5.3 & -0.9 & -1.4 & -3.0 & -3.3 & -3.5 \\
\hline Broad money 4/ & 17.6 & 16.9 & 16.7 & 17.8 & 27.7 & 26.1 & 25.5 & 22.5 \\
\hline Including foreign currency deposits & 17.2 & 16.1 & 15.9 & 17.4 & 27.3 & 25.6 & 25.1 & 22.1 \\
\hline M1 4/ & 11.8 & 17.5 & 21.0 & 9.1 & 32.4 & 39.0 & 35.0 & 29.9 \\
\hline M0 4/ & 11.9 & 12.7 & 12.1 & 12.7 & 11.8 & -0.8 & 22.0 & 15.8 \\
\hline Quasi money & 21.1 & 16.6 & 14.3 & 23.2 & 25.2 & 19.7 & 20.9 & 18.8 \\
\hline Reserve money & 9.3 & 20.8 & 30.6 & 27.3 & 11.4 & -0.8 & 6.9 & -1.7 \\
\hline Net foreign assets of PBC 5/ & 36.5 & 35.4 & 45.5 & 30.2 & 14.0 & 1.5 & 0.8 & 1.4 \\
\hline Net domestic assets of PBC 5/ & -17.7 & -11.2 & -15.0 & -7.9 & -5.6 & -7.8 & 1.8 & -0.2 \\
\hline \multicolumn{9}{|l|}{ Reserve ratios $6 /$} \\
\hline Required reserves & 7.5 & 9.0 & 14.5 & 15.0 & 15.0 & 15.5 & 16.0 & 16.0 \\
\hline Excess reserves & 4.2 & 4.8 & 3.3 & 5.1 & 3.1 & $\ldots$ & $\ldots$ & $\ldots$ \\
\hline \multicolumn{9}{|l|}{ Memorandum items: } \\
\hline Money multiplier & 4.6 & 4.4 & 4.0 & 3.7 & 4.2 & 4.4 & 4.2 & 4.3 \\
\hline Forex deposits of residents (US\$ billi & 161.6 & 161.1 & 159.9 & 179.1 & 208.9 & 209.3 & 211.8 & 213.4 \\
\hline In percent of total deposits & 4.3 & 3.6 & 2.9 & 2.6 & 2.3 & 2.3 & 2.3 & 2.2 \\
\hline Forex loans of residents (US $\$$ billion) & 150.5 & 166.4 & 219.8 & 243.7 & 379.5 & 388.8 & 398.6 & 408.3 \\
\hline
\end{tabular}

Sources: CEIC Data Co., Ltd.; and IMF staff calculations.

$1 /$ Includes foreign currency operations of domestic financial institutiojns and domestic operations of foreign banks. In addition, some items were moved from "other items net" to "net credit to government."

2/ Twelve-month change as percent of beginning -period stock of monetary liabilities.

3/ The growth rates are corrected for the transfer of NPLs from banks to the AMCs.

4/ The growth rates are based on official announcements, which correct for the definitional changes in the series.

$5 /$ Twelve-month change as a percent of beginning-period reserve money stock.

$6 /$ In percent of total bank deposits. 
Table 5. China: General Government Budgetary Operations

\begin{tabular}{|c|c|c|c|c|c|c|c|}
\hline & \multirow[t]{2}{*}{2005} & \multirow[t]{2}{*}{2006} & \multirow[t]{2}{*}{2007} & \multirow[t]{2}{*}{2008} & \multirow[t]{2}{*}{2009} & 2010 & 2011 \\
\hline & & & & & & \multicolumn{2}{|c|}{ Proj. } \\
\hline & \multicolumn{7}{|c|}{ (In billions of yuan) } \\
\hline Revenue & 3,184 & 3,944 & 5,262 & 6,173 & 6,817 & 7,438 & 8,580 \\
\hline Tax revenue & 2,878 & 3,480 & 4,562 & 5,422 & 5,952 & 6,695 & 7,744 \\
\hline Taxes on income and profits & 750 & 954 & 1,196 & 1,490 & 1,548 & 1,746 & 2,007 \\
\hline Taxes on goods and services & 1,666 & 1,980 & 2,426 & 2,819 & 3,226 & 3,845 & 4,369 \\
\hline Other taxes (residual) & 339 & 424 & 745 & 784 & 905 & 770 & 992 \\
\hline Nontax revenue (residual) & 306 & 464 & 700 & 750 & 866 & 743 & 836 \\
\hline Expenditure & 3,441 & 4,090 & 5,023 & 6,294 & 7,832 & 8,546 & 9,408 \\
\hline Primary & 3,360 & 3,993 & 4,917 & 6,138 & 7,672 & 8,364 & 9,194 \\
\hline Interest & 82 & 98 & 105 & 157 & 160 & 181 & 214 \\
\hline Overall balance & -257 & -146 & 239 & -122 & $-1,015$ & $-1,108$ & -828 \\
\hline Financing & 257 & 146 & -239 & 122 & 2,041 & 1,108 & 828 \\
\hline Domestic & 255 & 153 & -239 & 122 & 2,041 & 1,108 & 828 \\
\hline External & 2 & -6 & 0 & 0 & 0 & 0 & 0 \\
\hline Privatization and other & 0 & 0 & 0 & 0 & 0 & 0 & 0 \\
\hline \multicolumn{8}{|l|}{ Memo: Authorities' definition } \\
\hline Revenue & 3,165 & 3,876 & 5,132 & 6,133 & 6,848 & 7,469 & 8,560 \\
\hline Expenditure & 3,393 & 4,042 & 4,978 & 6,259 & 7,587 & 8,311 & 9,373 \\
\hline \multirow[t]{2}{*}{ Overall balance } & -228 & -166 & 154 & -126 & -740 & -842 & -813 \\
\hline & \multicolumn{7}{|c|}{ (In percent of GDP) } \\
\hline Revenue & 17.2 & 18.2 & 19.8 & 19.7 & 20.0 & 20.0 & 20.5 \\
\hline Tax revenue & 15.6 & 16.1 & 17.2 & 17.3 & 17.5 & 18.0 & 18.5 \\
\hline Taxes on income and profits & 4.1 & 4.4 & 4.5 & 4.7 & 4.5 & 4.7 & 4.8 \\
\hline Taxes on goods and services & 9.0 & 9.2 & 9.1 & 9.0 & 9.5 & 10.3 & 10.4 \\
\hline Other taxes (residual) & 1.8 & 2.0 & 2.8 & 2.5 & 2.7 & 2.1 & 2.4 \\
\hline Nontax revenue (residual) & 1.7 & 2.1 & 2.6 & 2.4 & 2.5 & 2.0 & 2.0 \\
\hline Expenditure & 18.6 & 18.9 & 18.9 & 20.0 & 23.0 & 23.0 & 22.5 \\
\hline Primary & 18.2 & 18.5 & 18.5 & 19.5 & 22.5 & 22.5 & 22.0 \\
\hline Interest & 0.4 & 0.5 & 0.4 & 0.5 & 0.5 & 0.5 & 0.5 \\
\hline Overall balance & -1.4 & -0.7 & 0.9 & -0.4 & -3.0 & -3.0 & -2.0 \\
\hline Financing & 1.4 & 0.7 & -0.9 & 0.4 & 6.0 & 3.0 & 2.0 \\
\hline Domestic & 1.4 & 0.7 & -0.9 & 0.4 & 6.0 & 3.0 & 2.0 \\
\hline External & 0.0 & 0.0 & 0.0 & 0.0 & 0.0 & 0.0 & 0.0 \\
\hline \multicolumn{8}{|l|}{ Memorandum items: } \\
\hline Debt & 17.6 & 16.2 & 19.6 & 17.0 & 17.7 & 19.2 & 19.0 \\
\hline Domestic & 17.2 & 15.9 & 19.4 & 16.8 & 17.5 & 19.1 & 18.9 \\
\hline External & 0.4 & 0.3 & 0.2 & 0.2 & 0.1 & 0.1 & 0.1 \\
\hline \multicolumn{8}{|l|}{ Cyclically adjusted balance } \\
\hline (percent of potential GDP) & -1.0 & -0.6 & 0.3 & -0.9 & -3.2 & -3.3 & -2.2 \\
\hline Nominal GDP (yuan billions) & 18,494 & 21,631 & 26,581 & 31,405 & 34,051 & 37,151 & 41,811 \\
\hline \multicolumn{8}{|l|}{ Authorities' definition } \\
\hline Revenue & 17.1 & 17.9 & 19.3 & 19.5 & 20.1 & 20.1 & 20.5 \\
\hline Expenditure & 18.3 & 18.7 & 18.7 & 19.9 & 22.3 & 22.4 & 22.4 \\
\hline Overall balance & -1.2 & -0.8 & 0.6 & -0.4 & -2.2 & -2.3 & -1.9 \\
\hline
\end{tabular}

Sources: CEIC Data Co., Ltd.; and IMF staff estimates. 
Table 6. China: Illustrative Medium-Term Scenario 1/

\begin{tabular}{|c|c|c|c|c|c|c|c|c|c|c|}
\hline & 2006 & 2007 & 2008 & 2009 & 2010 & 2011 & 2012 & 2013 & 2014 & 2015 \\
\hline & & & & & \multicolumn{6}{|c|}{ Projections } \\
\hline & \multicolumn{10}{|c|}{ (Percent change) } \\
\hline Real GDP & 12.7 & 14.2 & 9.6 & 9.1 & 10.5 & 9.6 & 9.5 & 9.5 & 9.5 & 9.5 \\
\hline Total domestic demand & 11.5 & 12.7 & 9.7 & 14.8 & 11.5 & 9.4 & 9.1 & 9.0 & 8.9 & 8.9 \\
\hline Consumption & 9.8 & 11.1 & 8.6 & 9.9 & 13.2 & 11.0 & 10.9 & 10.7 & 10.4 & 10.3 \\
\hline Investment & 13.6 & 14.7 & 11.0 & 20.4 & 9.7 & 7.6 & 7.1 & 7.1 & 7.1 & 7.2 \\
\hline Fixed & 12.8 & 13.4 & 9.7 & 24.6 & 10.1 & 7.9 & 7.4 & 7.3 & 7.3 & 7.4 \\
\hline Inventories 2/ & 0.6 & 0.8 & 0.8 & -1.0 & 0.0 & 0.0 & 0.0 & 0.0 & 0.0 & 0.0 \\
\hline Net exports $2 /$ & 2.0 & 2.5 & 0.8 & -4.3 & -0.5 & 0.6 & 0.8 & 0.8 & 0.9 & 1.0 \\
\hline \multirow[t]{2}{*}{ Consumer prices (average) } & 1.5 & 4.8 & 5.9 & -0.7 & 3.5 & 2.7 & 2.0 & 2.0 & 2.0 & 2.0 \\
\hline & \multicolumn{10}{|c|}{ (In percent of GDP) } \\
\hline Total capital formation & 43.0 & 41.7 & 44.0 & 47.7 & 50.0 & 49.2 & 48.3 & 47.4 & 46.5 & 45.6 \\
\hline Gross national saving & 52.3 & 52.4 & 53.7 & 53.6 & 55.0 & 54.5 & 54.2 & 53.9 & 53.7 & 53.6 \\
\hline Fiscal balance & -0.7 & 0.9 & -0.4 & -3.0 & -3.0 & -2.0 & -1.3 & -0.9 & -0.4 & 0.1 \\
\hline Revenue & 18.2 & 19.8 & 19.7 & 20.0 & 20.4 & 20.9 & 21.6 & 22.1 & 22.6 & 23.2 \\
\hline Expenditure & 18.9 & 18.9 & 20.0 & 23.0 & 23.4 & 22.9 & 23.0 & 23.0 & 23.1 & 23.1 \\
\hline \multirow[t]{2}{*}{ Current account balance } & 9.3 & 10.6 & 9.6 & 6.0 & 5.0 & 5.3 & 5.8 & 6.5 & 7.2 & 8.0 \\
\hline & \multicolumn{10}{|c|}{ (In billions of U.S. dollars) } \\
\hline Current account balance & 253 & 372 & 436 & 297 & 266 & 313 & 386 & 482 & 594 & 736 \\
\hline Trade balance & 218 & 315 & 361 & 250 & 212 & 266 & 331 & 409 & 511 & 643 \\
\hline Exports & 970 & 1,220 & 1,435 & 1,204 & 1,610 & 1,948 & 2,268 & 2,644 & 3,099 & 3,645 \\
\hline (Percent change) & 27 & 26 & 18 & -16 & 34 & 21 & 16 & 17 & 17 & 18 \\
\hline Imports & 752 & 905 & 1,074 & 954 & 1,399 & 1,682 & 1,936 & 2,235 & 2,587 & 3,003 \\
\hline (Percent change) & 20 & 20 & 19 & -11 & 47 & 20 & 15 & 15 & 16 & 16 \\
\hline Capital and financial account, net & 7 & 74 & 19 & 145 & 45 & -20 & -131 & -192 & -284 & -348 \\
\hline Capital account & 4 & 3 & 3 & 4 & 4 & 4 & 4 & 4 & 4 & 4 \\
\hline Direct investment, net & 57 & 121 & 94 & 34 & 13 & -2 & -17 & -33 & -50 & -64 \\
\hline Portfolio investment, net & -68 & 19 & 43 & 39 & -11 & -11 & -56 & -101 & -176 & -226 \\
\hline Other investment, net & 13 & -70 & -121 & 68 & 40 & -10 & -61 & -61 & -61 & -61 \\
\hline Errors and omissions & 25 & 15 & 24 & -44 & 0 & 0 & 0 & 0 & 0 & 0 \\
\hline Change in reserves (- indicates increase) & -285 & -461 & -480 & -399 & -311 & -293 & -255 & -290 & -309 & -388 \\
\hline \multicolumn{11}{|l|}{ Memorandum item: } \\
\hline Nominal GDP (in billions of yuan) & 21,631 & 26,581 & 31,405 & 34,051 & 37,151 & 41,811 & 46,849 & 52,364 & 58,533 & 65,391 \\
\hline
\end{tabular}

Sources: CEIC Data Co., Ltd.;and IMF staff estimates and projections.

1/ Following convention, the scenario assumes a constant real exchange rate and a continuation of the current policy framework.

2/ Contribution to annual growth in percent. 
Table 7. China: Public Sector Debt Sustainability Framework

(In percent of GDP, unless otherwise indicated)

\begin{tabular}{llll}
\multicolumn{4}{c}{ Actual } \\
\hline $20062007 \quad 2008 \quad 2009$
\end{tabular}

Projections

\begin{tabular}{llllll}
\hline 2010 & 2011 & 2012 & 2013 & 2014 & 2015
\end{tabular}

I. Baseline Projections

Public sector debt 1/

Of which: foreign-currency denominated

Change in public sector debt

Identified debt-creating flows $(4+7+12)$

Primary deficit

Revenue and grants

Primary (noninterest) expenditure

Automatic debt dynamics 2 /

Contribution from interest rate/growth differential 3/

Of which: contribution from real interest rate

Of which: contribution from real GDP growth

Contribution from exchange rate depreciation 4/

Other identified debt-creating flows

Privatization receipts (negative)

Recognition of implicit or contingent liabilities

Other (specify, e.g., bank recapitalization)

Residual, including asset changes (2-3)

Public sector debt-to-revenue ratio $1 /$

Gross financing need 5/

In billions of U.S. dollars

Key macroeconomic and fiscal assumptions

Real GDP growth (in percent)

Average nominal interest rate on public debt (in percent) 6/

Average real interest rate (nominal rate minus change in GDP deflator, in percent)

Exchange rate (LC per U.S. dollar)

Nominal depreciation of local currency (LC per dollar)

Exchange rate (U.S. dollar per LC)

Nominal appreciation (increase in U.S. dollar value of local currency, in percent)

Inflation rate (GDP deflator, in percent)

Growth of real primary spending (deflated by GDP deflator, in percent)

Primary deficit

\section{A. Alternative scenarios}

A1. Key variables are at their historical averages in 2010-15 7/

A2. No policy change (constant primary balance) in 2010-15

\section{B. Bound tests}

B1. Real interest rate is at baseline plus one standard deviations

B2. Real GDP growth is at baseline minus one-half standard deviation

B3. Primary balance is at baseline minus one-half standard deviation

B4. Combination of B1-B3 using one-quarter standard deviation shocks

B5. One time 30 percent real depreciation in 2010 8/

B6. 10 percent of GDP increase in other debt-creating flows in 2010

$\begin{array}{rrrr}16.2 & 19.6 & 17.0 & 17.7 \\ 0.3 & 0.2 & 0.2 & 0.1 \\ -1.4 & 3.4 & -2.6 & 0.7 \\ -2.4 & -4.7 & -3.4 & 1.7 \\ 0.2 & -1.3 & -0.1 & 2.5 \\ 18.2 & 19.8 & 19.7 & 20.0 \\ 18.5 & 18.5 & 19.5 & 22.5 \\ -2.6 & -3.5 & -3.3 & -0.9 \\ -2.1 & -2.6 & -2.5 & -0.8 \\ -0.2 & -0.7 & -0.9 & 0.6 \\ -1.9 & -1.9 & -1.6 & -1.4 \\ -0.5 & -0.8 & -0.8 & 0.0 \\ 0.0 & 0.0 & 0.0 & 0.0 \\ 0.0 & 0.0 & 0.0 & 0.0 \\ 0.0 & 0.0 & 0.0 & 0.0 \\ 0.0 & 0.0 & 0.0 & 0.0 \\ 1.0 & 8.2 & 0.7 & -0.9 \\ 88.8 & 99.0 & 86.3 & 88.4 \\ 3.7 & 1.2 & 2.6 & 5.2 \\ 99.2 & 43.5 & 117.1 & 257.5\end{array}$

10-Year

Historical

Average

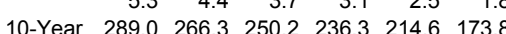

Standard

$\underline{\text { Deviation }}$

$\begin{array}{rrrr}12.7 & 14.2 & 9.6 & 9.1 \\ 3.0 & 3.0 & 3.0 & 3.0 \\ -0.8 & -4.6 & -4.8 & 3.6 \\ 7.8 & 7.3 & 6.8 & 6.8 \\ -3.2 & -6.5 & -6.4 & -0.1 \\ 0.1 & 0.1 & 0.1 & 0.1 \\ 3.3 & 6.9 & 6.9 & 0.1 \\ 3.8 & 7.6 & 7.8 & -0.6 \\ 14.5 & 14.4 & 15.8 & 25.8 \\ 0.2 & -1.3 & -0.1 & 2.5\end{array}$

$\begin{array}{rrrrrrr}2.4 & 10.5 & 9.6 & 9.5 & 9.5 & 9.5 & 9.5 \\ 1.4 & 3.0 & 3.8 & 3.6 & 3.6 & 3.7 & 3.7 \\ 4.1 & 4.2 & 1.1 & 1.3 & 1.5 & 1.6 & 1.7 \\ 0.5 & 6.8 & 6.8 & 6.9 & 6.9 & 6.7 & 6.7 \\ 2.7 & -0.2 & 0.2 & 0.4 & 0.2 & -1.8 & -1.8 \\ 0.0 & 0.1 & 0.1 & 0.1 & 0.1 & 0.1 & 0.1 \\ 2.9 & 0.2 & -0.2 & -0.4 & -0.2 & 1.8 & 1.8 \\ 3.4 & -1.2 & 2.7 & 2.3 & 2.1 & 2.1 & 2.1 \\ 4.1 & 8.5 & 5.4 & 9.1 & 8.6 & 8.7 & 8.7 \\ 1.4 & 2.1 & 0.8 & 0.0 & -0.7 & -1.3 & -2.0\end{array}$

II. Stress Tests for Public Debt Ratio

$\begin{array}{llllll}34.6 & 41.6 & 47.8 & 53.6 & 59.0 & 65.0\end{array}$ $\begin{array}{llllll}33.5 & 45.4 & 53.3 & 61.1 & 68.3 & 76.5\end{array}$

$\begin{array}{llllll}36.3 & 43.9 & 50.2 & 55.9 & 60.8 & 66.1 \\ 36.6 & 44.5 & 51.5 & 58.0 & 64.1 & 70.9 \\ 36.7 & 44.2 & 50.4 & 55.8 & 60.4 & 65.3 \\ 36.7 & 44.5 & 51.1 & 57.1 & 62.3 & 68.0 \\ 42.2 & 48.7 & 53.9 & 58.4 & 62.0 & 65.2 \\ 46.0 & 52.2 & 57.1 & 61.3 & 64.7 & 68.7\end{array}$

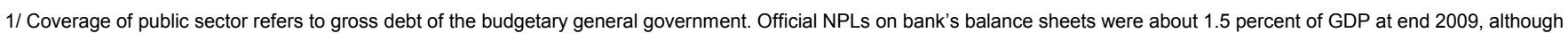

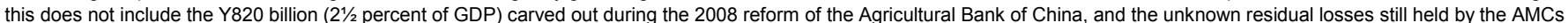

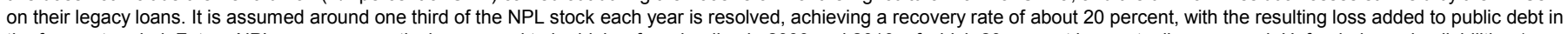

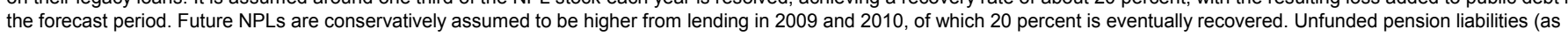
part of a transition) are assumed to be covered each year by the budget in 2010-15; interest will also be paid on these and the bonds issued to cover NPLs.

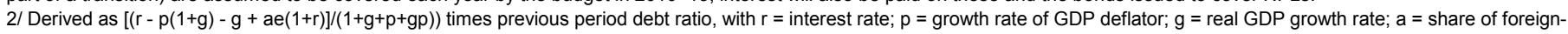
currency denominated debt; and $\mathrm{e}=$ nominal exchange rate depreciation (measured by increase in local currency value of U.S. dollar).

3 / The real interest rate contribution is derived from the denominator in footnote $2 /$ as $r-\pi(1+g)$ and the real growth contribution as $-\mathrm{g}$.

$4 /$ The exchange rate contribution is derived from the numerator in footnote $2 /$ as ae $(1+r)$.

$5 /$ Defined as public sector deficit, plus amortization of medium and long-term public sector debt, plus short-term debt at end of previous period.

6/ Derived as nominal interest expenditure divided by previous period debt stock.

7/ The key variables include real GDP growth; real interest rate; and primary balance in percent of GDP.

8/ Real depreciation is defined as nominal depreciation (measured by percentage fall in dollar value of local currency) minus domestic inflation (based on GDP deflator). 


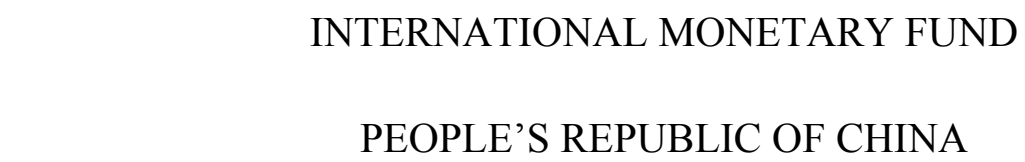

Staff Report for the 2010 Article IV Consultation-Informational Annex

Prepared by the Asia and Pacific Department

July 9,2010

Contents

Page

I. Fund Relations 2

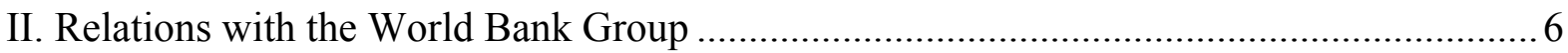

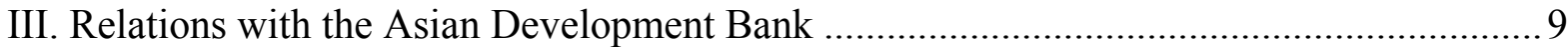

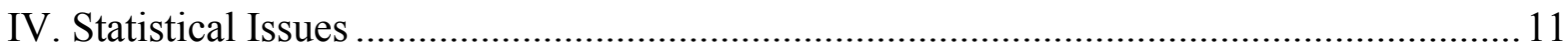

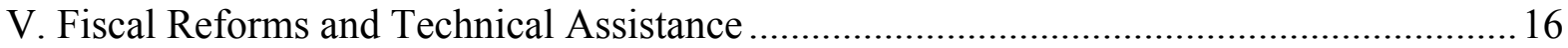




\section{AnNex I. China: Fund Relations}

(As of May 31, 2010)

I. Membership Status: Joined 12/27/45; Article VIII (December 1, 1996)

II. General Resources Account:

Quota

Fund holdings of currency

Reserve position in Fund

III. SDR Department:

Net cumulative allocation

Holdings
SDR Million

$8,090.10$

$6,515.09$

$1,575.06$

\section{SDR Million}

$6,989.67$

$8,052.39$
\% Quota

100.00

80.53

19.47

IV. Outstanding Purchases and Loans: None

V. Financial Arrangements:

$\begin{array}{ccccc}\text { Type } & \text { Approval Date } & \begin{array}{c}\text { Expiration } \\ \text { Date }\end{array} & \begin{array}{c}\text { Amount } \\ \text { Approved } \\ \text { (SDR million) }\end{array} & \begin{array}{c}\text { Amount Drawn } \\ \text { (SDR million) }\end{array} \\ \text { Stand-by } & 11 / 12 / 86 & 11 / 11 / 87 & 597.73 & 597.73\end{array}$

VI. Projected Obligations to Fund (SDR million; based on existing use of resources and present holdings of SDRs):

Principal

Charges/interest

Total

\begin{tabular}{ccccc}
\multicolumn{5}{c}{ Forthcoming } \\
$\mathbf{2 0 1 0}$ & $\mathbf{2 0 1 1}$ & $\mathbf{2 0 1 2}$ & $\mathbf{2 0 1 3}$ & $\mathbf{2 0 1 4}$ \\
\hline & 0.00 & 0.00 & 0.00 & 0.00 \\
& 0.06 & 0.06 & 0.06 & 0.06 \\
& 0.06 & 0.06 & 0.06 & 0.06
\end{tabular}

\section{Exchange Arrangements:}

1. China's exchange rate regime is currently classified as a stabilized arrangement. On July 21, 2005, the People's Bank of China (PBC) announced that the exchange rate of the renminbi against the U.S. dollar would be revalued upward by about 2.1 percent (from RMB 8.28/US\$ to RMB 8.11/US\$) and the exchange rate regime would move to a 
managed float in which renminbi's value is set with reference to a basket of currencies. The stated intention of the Chinese authorities was to increase the flexibility of the renminbi's exchange rate. The authorities indicated that they will not publish the currencies in the reference basket and their relative weight. The $\mathrm{PBC}$ indicated that it would adjust the exchange rate trading band as necessary to reflect market developments and financial and economic conditions. Under the new regime, the band around the daily trading price of the U.S. dollar against the renminbi was kept at \pm 0.3 percent around the central parity published by the $\mathrm{PBC}$ while the trade prices of the non-U.S. dollar currencies against the renminbi were allowed to move within a certain band announced by PBC, which was initially set at \pm 1.5 percent and increased to \pm 3 percent in September 2005. In August 2005, the governor of PBC revealed that U.S. dollars, Euro, Japanese yen, and Korean won were the main currencies included in the basket, and U.K. pound, the Thai baht, and the Russian ruble were among other currencies included in the basket. In May 2007, the band around the daily trading price of the U.S. dollar against the renminbi was widened to \pm 0.5 percent. After maintaining the renminbi closely linked to the U.S. dollar between July 2008 and June 2010, the PBC announced on June 19, 2010 a return to the managed floating exchange rate regime prevailing prior the global financial crisis with the exchange rate allowed to move up to \pm 0.5 percent from a central parity rate.

2. On January 4, 2006, over-the-counter (OTC) trading of spot foreign exchange was introduced with 13 banks initially designated as market makers and the number of market makers has since risen to 22 . The centralized spot foreign exchange trading system (CFETS) remains operative, but its central parity rate (renminbi against the U.S. dollar) is now based on a weighted average of CFETS and OTC transactions. Under the new system, CFETS first inquires prices from all market makers before the opening of the market on each business day, exclude the highest and lowest offers, and then calculates the weighted average of the remaining prices in the sample as the central parity for the renminbi against the U.S. dollar for the day. The weights for the market makers, which remain undisclosed, are determined by the CFETS in line with the transaction volumes of the respective market makers in the market.

3. China accepted the obligations of Article VIII, Sections 2, 3, and 4 of the Fund's Articles of Agreement on December 1, 1996. There are repatriation and surrender requirements on proceeds from exports and from invisible transactions and current transfers. Starting on August 13, 2007, all enterprises (domestic institutions) having foreign exchange revenue from foreign operation or from current accounts may keep foreign exchange receipts according to their operational needs in their current account foreign exchange accounts. Domestic institutions that had no current account foreign exchange revenue in the previous year are allowed to retain an initial limit of foreign exchange revenue equivalent to US\$500,000. Current account foreign exchange accounts with special sources and designated uses have limits of 100 percent of actual foreign currency income. In the case of exportimport and manufacturing enterprises that, because of actual operating needs, must retain all current account foreign exchange revenues, SAFE may determine their limits as 100 percent 
of actual foreign exchange revenue and actual needs. From invisible transaction, balances, if any, beyond operational needs must be sold to foreign exchange banks, with amount exceeding US\$50,000 requiring documents be submitted to SAFE. There are no measures currently in force that have been determined to be exchange restrictions subject to Fund jurisdiction. However, China has notified measures to the Fund, pursuant to procedures under the Executive Board Decision 144-(52/51), which apply to measures imposed solely for national or international security reasons.

4. Exchange controls continue to apply to most capital transactions. Effective on July 1, 2006, quotas on foreign exchange purchases for foreign direct investment (FDI) were abolished, and domestic investors were allowed to purchase foreign exchange to finance pre-FDI activities. Since December 1, 2002, qualified foreign institutional investors (QFIIs) have been allowed to invest domestically in A shares, subject to certain restrictions, and all nonresidents have been allowed to purchase B shares, which are denominated in U.S. dollars or Hong Kong dollars. The overall QFII quota was increased to US\$30 billion in December 2007 from US\$10 million. The Qualified Domestic Institutional Investor (QDII) scheme was introduced in 2004, and measures have since been taken to promote its development. Since May 1, 2006, residents can purchase up to US\$20,000 foreign exchange for depositing in banks or for current account transactions and this limit was raised to US\$50,000 in September 2006. Beyond the quota, purchases require relevant documents. In May 2007, the QDII scheme was expanded to allow qualified banks to invest retail funds in foreign equities. Effective July 5, 2007 the China Securities and Regulatory Commission extended QDII to securities and fund-management companies. The firms have to meet certain capital and other requirements. From April 2006, qualified insurance companies were also allowed to invest their own foreign exchange externally under the QDII scheme. In 2004, international financial institutions were approved to raise funds domestically in renminbi for use offshore, while in December 2007, it was announced that foreign-funded enterprises would be allowed to issue renminbi bonds. Other nonresidents are still not permitted to issue capital or money market securities in the domestic market. An annual foreign borrowing plan sets mandatory ceilings for all medium- and long-term borrowing by government departments and enterprises (except FFEs which are subject to individual limits negotiated in the investment approval process).

\section{Article IV Consultation:}

5. China is on the standard 12-month consultation cycle. The 2009 Article IV mission was concluded on July 8, 2009. The staff report was not published.

\section{Technical Assistance:}

6. Technical assistance provided in 2000 through January 2008 is summarized in Annex V. 


\section{Resident Representative:}

9. The resident representative office in Beijing was opened in October 1991. Mr. Il Houng Lee is the Senior Resident Representative and Mr. Murtaza Syed is the Resident Representative. 


\section{AnNex II. China: Relations With THE WORLd Bank GrouP ${ }^{1}$}

1. The World Bank has been active in China since 1980. World Bank commitments to China as of end-FY 2010 are expected to total about $\$ 47$ billion for 323 projects. About 75 of these projects are under implementation, as well as a significant number of trust funds, making China's portfolio one of the largest in the Bank. World Bank-supported projects are found in almost all parts of China and in many sectors of the economy, with infrastructure (transport, energy, urban development) accounting for more than half of the total portfolio, and rural development, social sectors (health, education, social protection), and direct poverty reduction programs comprising the remainder. Roughly three-quarters of Bank supported activities have environmental objectives and a strong environment focus runs across sectors with environment-related projects in energy, urban wastewater, water supply and sanitation, and rural development.

2. The nature of the China-World Bank partnership has also changed over time. Initially, China looked to the Bank for technical assistance to introduce basic economic reforms, modern project management methodologies, and new technologies. With time, the partnership increasingly focused on institutional strengthening and knowledge transfer. As China has successfully adopted new practices and registered unprecedented development achievements, the remaining development challenges have become less amenable to standard solutions. Instead, China has engaged the Bank in a two-way exchange to tailor unique approaches that match local realities and capacity with global experiences. The Bank has also increasingly sought to support China in sharing its own important development experiences and knowledge with the rest of the world. Going forward, China is placing an increasing emphasis on growth that is balanced with social and environmental concerns. Given the resources constraint and difficult reform challenges, innovative approaches, ideas, and system reforms will be critical to China's achieving its national goals.

3. The World Bank Group Country Partnership Strategy (CPS), endorsed by the WB Board in May 2006, covers both lending and non-lending activities and is designed to support the five strategic themes consistent with China's $11^{\text {th }}$ Five-Year Program: integrating China into the world economy, reducing poverty and inequality, addressing resource scarcities and environmental challenges, strengthening the financial sector, and improving market and public institutions. The mid-term Country Partnership Strategy Progress Report (Report 46896-CN) completed in January 2009 determined that the Strategy is well on track to fulfill or exceed most strategic targets. The Progress Report notes that implementation of the CPS has largely proceeded as envisaged, however there has been a more intensified engagement in a number of areas, including: China's integration into the world economy, especially regarding south-south learning; energy efficiency, environment and climate change;

\footnotetext{
${ }^{1}$ Prepared by World Bank staff.
} 
and, more recently, integrated urban-rural development. Bank support for disaster and risk management generally, and earthquake reconstruction, specifically, in the wake of the tragic May 2008 Sichuan earthquake has been mobilized. The Bank is also providing support to help the government in managing the impacts of the current global economic downturn.

4. In FY 2009 lending totaled $\$ 2.3$ billion in IBRD loans for 13 projects. These projects focus on urban environment improvement, transportation (urban transport, inland waterways, railways and provincial highways), vocational training, eco-farming, flood and watershed management, coal bed methane development and a cultural and natural heritage project. The Bank also supported reconstruction following the Wenchuan earthquake with a $\$ 710$ million loan. For FY 2010 we envisage lending of $\$ 1.4$ billion in total for 14 projects in support of poverty reduction, eco-livestock development, food safety, sustainable forestry, urban environment and transport, river basin management, biomass heat power cogeneration and vocational education. As in the past, these lending operations are knowledge-based: successful pilots may be scaled up and replicated in other provinces or at the national level.

5. In addition to financial assistance, the provision of economic analysis, policy advice, technical assistance and training is an essential part of the Bank's partnership with China. The Bank has responded to the country's evolving needs, by having a better balance between comprehensive reports on issues requiring detailed technical analysis and more demanddriven rapid delivery brief policy notes, supplemented by other forms of collaboration such as senior-level workshops and focused study tours.

6. Key analyses that were recently released include: Quarterly Economic Updates, reports on trade issues, pension reform, health care reform, improving rural-urban linkages in Chongqing and Guangdong, rural compulsory education, rural urban migration, energy intensity, capital market development, land market reform, and financial sector development.

7. The China Economic Reform Implementation project, a technical cooperation loan, was approved in FY 2006. A large program of technical assistance has also been financed by trust funds from within and outside the Bank, covering issues such as environmental management, financial sector reform, statistical reform, poverty issues, and social security. The World Bank Institute carries out a wide range of training, peer learning and South-South knowledge exchange programs, including through use of the Global Development Learning Network.

8. China has also signed 20 carbon purchase agreements with the World Bank totaling USD 1.297 billion as of June 2010 .

Representation: The People's Republic of China assumed China's representation in the World Bank on May 15, 1980. 
Capital Subscription: China's current subscription is 44,799 shares, amounting to US $\$ 5,404.3$ billion, which is 2.85 percent of the total subscribed shares of IBRD. China has fully subscribed to its share allocation.

Resident Mission: A resident IBRD office in Beijing has been in operation since October 1985. In October 1997, responsibility for managing the Bank's total program for China was decentralized to the Beijing office.

International Finance Corporation (IFC): । As of June 15, 2010, IFC had invested $\$ 4.65$ billion in 193 projects across all major sectors ( $\$ 1.65$ billion in equity, $\$ 2.00$ billion in loans, $\$ 754$ million in syndications and \$250 million in guarantees). IFC's early partners were mostly foreign investors, but now 85 percent of IFC's clients are domestic companies. The investment program for FY 2010 is expected to be approximately $\$ 420$ million. IFC's China strategy focuses on climate change, balanced rural-urban development, and South-South investment particularly focused on Africa. A resident IFC office in Beijing has been in operation since 1992. In July 2000, IFC began to operate its regional headquarters in Hong Kong. In 2002, IFC opened an office in Chengdu to provide advisory services to small and medium enterprises (SMEs) in Western region of China. 


\section{ANNEX III. China: RELATIONS WITH THE ASIAN DEVELOPMENT BANK ${ }^{1}$}

1. The Asian Development Bank's (ADB) partnership with the People's Republic of China (PRC) has evolved since the PRC became a member of ADB in March 1986. The PRC is ADB's second largest shareholder among regional members and the third largest overall, as well as an important middle-income country client. By the end of 2009, the PRC's cumulative borrowing from ADB reached $\$ 22.2$ billion with 156 loans for public sector projects. Of the total public sector loans, 56 percent was allocated to the transport sector, followed by water supply, sanitation and waste management (13 percent), energy (12 percent), agriculture and natural resources ( 8 percent), multisector (5 percent), industry and trade ( 3 percent), and finance ( 3 percent). Over the past 23 years, ADB has helped finance 29 private sector projects in the PRC totaling \$2.1 billion.

2. ADB also funds technical assistance for the PRC. By the end of 2009, ADB had provided a total of $\$ 331.8$ million in grants for 598 technical assistance projects, consisting of $\$ 100.1$ million for project preparation and $\$ 231.7$ million for policy advice and capacity development.

3. Overall, the PRC has demonstrated strong capabilities in implementing projects. The good performance shows the strong sense of project ownership among agencies involved in the design, implementation, and management of projects, as well as the rigorous screening process for development projects, particularly those proposed for external financing. Loan disbursement and contract award performance is good.

4. The PRC has demonstrated its strong partnership with ADB by contributing \$35 million to the Asian Development Fund, and establishing the \$20 million Poverty Reduction and Regional Cooperation Fund. The Poverty Reduction and Regional Cooperation Fund - the first fund established in ADB by a developing member countryprovides technical assistance for projects in the Greater Mekong Subregion and in Central Asia.

5. In 2008, the Asian Development Bank issued its most recent Country Partnership Strategy (CPS) for the People's Republic of China, covering 2008 to 2010. The CPS was developed in close cooperation with the PRC Government, and supports the government's implementation of the $11^{\text {th }} 5$-Year Plan through four strategic pillars: (i) inclusive growth and balanced development; (ii) resource efficiency and environmental sustainability; (iii) regional cooperation and public goods; and (iv) the enabling environment for private sector development. In addition, two themes cut across all of ADB's operations: (i) knowledge and innovation; and (ii) governance. A new CPS is currently under preparation, covering 2011 to 2015.

\footnotetext{
${ }^{1}$ Prepared by Asian Development Bank staff.
} 
6. Projected public sector lending in 2010-11 will total about \$2.98 million, of which 42 percent will support transport infrastructure and maintenance; 22 percent for agriculture, rural development and natural resource management; 22 percent for urban development, water supply and sanitation improvement; and 14 percent for the energy sector. With 85 percent of the projects located in the western and central regions, and all projects having an environmental focus, the pipeline closely follows the strategic pillars of the CPS, particularly its emphasis on inclusive growth and environmental protection.

7. The ADB's lending program will continue to be supported by technical assistance. Grants for technical assistance program are expected to be $\$ 15$ million to $\$ 20$ million annually. To enhance the strategic focus of ADB operations, better meet the goals of the government's development plans, and address pressing concerns on environmental protection and energy preservation, several advisory technical assistance projects are directly related to resource efficiency, environment protection, and climate change initiatives.

Table III.1. China: ADB's Commitments and Disbursements (Public Sector Loans), 1993-2009

(In millions of U.S. dollars)

\begin{tabular}{lrr}
\hline Year & Commitments 1/ & Disbursements 2/ \\
\hline 1993 & 1,031 & 371 \\
1994 & 1,618 & 492 \\
1995 & 2,304 & 558 \\
1996 & 3,282 & 707 \\
1997 & 4,033 & 715 \\
1998 & 4,518 & 818 \\
1999 & 5,337 & 792 \\
2000 & 6,159 & 832 \\
2001 & 6,748 & 1,313 \\
2002 & 7,563 & 782 \\
2003 & 8,075 & 705 \\
2004 & 8,733 & 636 \\
2005 & 11,060 & 892 \\
2006 & 11,794 & 984 \\
2007 & 13,214 & 1,190 \\
2008 & 14,526 & 1,234 \\
2009 & 15,647 & 1,342 \\
\hline
\end{tabular}

1/ Refers to cumulative contract awards.

2/ Refers to disbursements for the year. 


\section{ANNEX IV. CHINA: STATISTICAL ISSUES}

1. While economic statistics are adequate for surveillance purposes, weakness remain in the quality of the data, including coverage, frequency and timeliness. Nevertheless, China has made significant strides in bringing its economic and financial statistics into line with international good practice. In April 2002, China began participation in the Fund's GDDS, and it certified and updated the metadata posted on the Fund's DSBB (the most comprehensive documentation of economic and financial statistics available in English), in early 2009 (with the exception of financial sector and social demographic sector, which were certified in 2006). The technical assistance (TA) and training evaluation mission in March 2009 concluded that STA's TA and training missions to China were highly appreciated by all recipient agencies.

\section{Real Sector Statistics}

2. The National Bureau of Statistics (NBS) compiles and disseminates annual GDP by activity in current and constant prices (2005). The techniques for deriving volume measures of GDP are not sound and need to be improved. GDP by expenditure is compiled at current and constant 2000 prices, but the constant price estimates are not published. Quarterly GDP estimates are compiled in cumulative form, with minimal revisions, making it difficult to assess quarterly developments accurately or to make seasonal adjustments. Data on the expenditure components of GDP are not available on a quarterly basis. Nevertheless, the NBS has made a number of improvements to the range and quality of national accounts data, the most important being improving the exhaustiveness of the GDP estimates by activity. Further improvements are intended, including the adoption of the 1993 System of National Accounts, further improvements to quarterly GDP estimates. However, no target dates have been set. As in other countries, rapid economic change, including the expansion of the private sector, presents new problems for data compilation. The ability to change the collection of data is restricted by the decentralized nature of the statistical system. Extensive technical assistance has been provided from multilateral and bilateral institutions.

3. Monthly industrial production, retail sales, and fixed investment indices are compiled with the corresponding month of the previous year as a base period. However, no chainlinked time series are produced. Data revisions tend to be made without publishing the entire revised series.

4. Labor market statistics - including employment and wage data — are not comprehensive, and are only available on an annual basis, with considerable lag.

5. In January 2001, the NBS began to publish an annually-chained Laspeyres price index, which more accurately reflects consumer spending patterns (e.g., the weight of services increased, while the weight of food declined). The number of survey items has been expanded to around 700. The most recent weights of the major CPI components were provided to the staff in 2006. Prior to 2001, the index was compiled and disseminated on a 
month to month and year to year basis using current year weights for most items. The data for this index are for the period 1978-2000.

\section{Government Finance Statistics}

6. Serious data shortcomings continue to hamper fiscal analysis. Budgetary data exclude spending associated with domestic bond proceeds on-lent to local governments and official external borrowing. Also, data on the social and extra budgetary funds are only provided annually and with a long lag. Expenditure classification remains poor, mainly because data are not classified by economic type. However, the situation should gradually improve with the recent introduction of a revised budget classification system, starting with the 2010 budget. The authorities have indicated an intention to develop accrual based measures of fiscal performance over the medium term while also strengthening the compilation of cash based GFS.

7. China has reported general government cash-based budget data for 2003-2007 following the GFSM 2001 methodology for publication in the 2009 GFS Yearbook. However, these data are limited, with no data provided on government debt and transactions in financial assets and liabilities. The revenue classification does not fully distinguish between revenue and grants, tax and nontax revenue, and current and capital revenue. The presentation of expenditure by function is largely aligned with international best practice. Owing to source data issues, the authorities have not yet been able to report a GFSM 2001 Statement of Sources and Uses of Cash for the budgetary central government accounts on a subannual basis. As a result, there are no fiscal data for China on the Principal Global Indicators website.

\section{Monetary and Financial Statistics}

8. In recent years, improvements have been made by the People's Bank of China (PBC) in monetary and financial statistics. The most notable progress made by the $\mathrm{PBC}$ are as follows: (1) expanding the coverage of financial institutions; (2) adjusting the sectorization of financial corporations; (3) improving the "all accounts" reporting system; and (4) improving data dissemination following the GDDS recommendations, such as disseminating advance release calendars on the PBC's websites. On financial soundness indicators (FSIs), China began reporting annual data on core FSIs to the Fund under a pilot project although no agreement has been given by the authorities for publication of these data.

9. However, the monetary and banking surveys lack sufficient detail with regard to bank claims on the government, hampering the estimation of the fiscal deficit from the financing side. The reported net foreign assets position of PBC does not include exchange rate valuation effects and interest earnings on foreign reserves. The $\mathrm{PBC}$ has also ceased to report separate data on central government deposits in its balance sheet since April 2005 because the MOF no longer distinguishes between central and other government deposit accounts. This change has led to breaks in data series of monetary base and monetary aggregates. In 
addition, detailed breakdowns of bank credit by industry, and by borrower (including by the various elements of the state and nonstate sectors), are not publicly available.

10. Due to the restructuring of the banking sector, new statistical issues have arisen, such as how to record the transfer of nonperforming loans to asset management companies, and how to sectorize these companies in the banking survey. The monetary and financial statistics mission that visited Beijing in 2007 and 2009 made recommendations for addressing these issues. These missions also assisted the authorities in addressing issues related to (1) the implementation of Standardized Report Forms; (2) expansion of data coverage to include other financial corporations; and (3) compilation of FSIs and reporting of FSI data and metadata using the standard templates. .

11. A financial statistics mission will visit China in the $2^{\text {nd }}$ half of 2010 to assist the authorities in advancing their work in addressing data issues on monetary and financial statistics and financial soundness indicators.

\section{External Sector Statistics}

12. The State Administration of Foreign Exchange (SAFE) relies on an International Transactions Reporting System (ITRS) which produces data derived from information on foreign exchange transactions conducted by banks. To supplement the ITRS, data on travel credits and trade credits are collected through periodic sample surveys, while additional data are collected from other government agencies and reports on balance sheet information from financial institutions and data on portfolio investment and direct investment.

13. The data are compiled (in U.S. dollars) largely in accordance with the fifth edition of the Balance of Payments Manual (BPM5). Preliminary semi-annual (January-June) data are compiled and disseminated within three months after the end of the reference period while annual data are disseminated four to five months following the end of the reference period. It appears that the authorities may be close to being able to publish quarterly estimates of the balance of payments. Within the current account, component detail is available on goods, services, income, and transfers. Data on the financial account, with significant component detail for functional categories, and data on the capital account are also available. Data on China's international investment position (IIP) are published for the period 2004-2009.

14. The coverage of direct investment transactions remains a problematic issue in the balance of payments and IIP statistics, although progress is being made in developing these statistics. Data on transactions for the nonfinancial sector, received mainly from the Ministry of Commerce (formerly Ministry of Foreign Trade and Cooperation), apparently do not cover all required elements such as disinvestments. In 2007, inward direct investment stock data of the nonfinancial sector were based on new source data collected through the "Joint Annual Review and Evaluation of Overall Performance on China's Inward FDI," a joint government department effort to collect performance data from foreign-funded enterprises. Since ITRS is the major data source for BOP, in order to ensure its smooth operation, regular training programs for staff in the provincial offices of SAFE were recommended. In addition, in 
January 2003 a legislative guarantee for the improvement of the quality of ITRS reporting entitled "The Checking System on Balance of Payments Reporting Data (experimental)" was promulgated by the SAFE. An upgraded version of the ITRS has been used since 2009.

15. The Fund has provided extensive technical assistance and training to improve balance of payments and IIP statistics. At the Joint China-IMF Training Program in Dalian, STA conducted a specialized seminar on Cross-border Stocks and Flows in June 2006 and a Balance of Payments and IIP course in June 2007. Following China's agreement to participate in the Coordinated Direct Investment Survey (CDIS), STA visited Beijing in April 2008 to conduct an interagency meeting on the CDIS. At the request of SAFE, STA also conducted a one-week seminar on the new draft Balance of Payments and International Investment Position Manual (BPM6) in Kunming, China.

16. The Fund has also provided technical assistance on the coverage, timeliness, and periodicity of data on official reserves, reserves-related liabilities, as well as on other external assets and liabilities, financial derivative activities, and other contingent and potential liabilities. Despite an ostensibly modest level of external vulnerability, there remains a need to strengthen external debt monitoring and compilation. STA conducted a seminar on external debt statistics in August 2005 as part of the China Training Program. In January 2010, China started submitting total and public external debt data for the Quarterly External Debt Statistics (QEDS) database, a notable step forward.

\section{Data Reporting to STA for Publications}

17. Despite improvements in reporting a number of breaks remain in the series, and comparable historical data are not available. Reporting of data to STA for IFS has, in the past, tended to be sporadic and with a considerable time lag. Following the introduction of new reporting arrangements, the timeliness of consumer price, industrial production, trade value, and total GDP data in IFS has improved substantially. However, the range of information is relatively limited, with no data published on producer prices, wages, trade volumes or prices/unit values. The authorities have recently resumed reporting data on international reserves for IFS. However, the monthly time series will now be submitted every three months, instead of every month.

\section{Data Dissemination to the Public}

18. The publication of a quarterly statistical bulletin by the PBC has significantly improved the timing and coverage of publicly available data on the monetary accounts and the main real sector indicators. However, the monthly statistical publications do not contain many time series (e.g., unemployment) or the disaggregation necessary for analysis. Moreover, several important time series, particularly on the main fiscal variables, are not released in a systematic and timely manner. Extensive annual economic data are available in various statistical yearbooks, but these are published nine months or more after the end of the year. 


\section{China-Table of Common Indicators Required for Surveillance}

(As of June 17, 2010)

\begin{tabular}{|c|c|c|c|c|c|}
\hline & $\begin{array}{l}\text { Date of } \\
\text { Latest } \\
\text { Observation }\end{array}$ & $\begin{array}{l}\text { Date } \\
\text { Received }\end{array}$ & $\begin{array}{l}\text { Frequency of } \\
\text { Data }^{9}\end{array}$ & $\begin{array}{l}\text { Frequency of } \\
\text { Reporting }^{9}\end{array}$ & $\begin{array}{l}\text { Frequency of } \\
\text { Publication }^{9}\end{array}$ \\
\hline Exchange rates & $06 / 17 / 10$ & $06 / 17 / 10$ & $\mathrm{D}$ & $M^{9}$ & D \\
\hline $\begin{array}{l}\text { International reserve assets and reserve } \\
\text { liabilities of the monetary authorities }{ }^{1}\end{array}$ & $03 / 10$ & $06 / 10$ & M & M & M \\
\hline Reserve/base money & $05 / 10$ & $06 / 10$ & $Q, M$ & $Q, M$ & $Q, M$ \\
\hline Broad money & $05 / 10$ & $06 / 10$ & M & M & M \\
\hline Central bank balance sheet & $04 / 10$ & $06 / 10$ & M & M & M \\
\hline $\begin{array}{l}\text { Consolidated balance sheet of the banking } \\
\text { system }\end{array}$ & $05 / 10$ & $06 / 10$ & M & M & M \\
\hline Interest rates ${ }^{2}$ & $06 / 17 / 10$ & $06 / 17 / 10$ & 11 & 11 & 11 \\
\hline Consumer price index ${ }^{3}$ & $05 / 10$ & $06 / 14 / 10$ & M & M & M \\
\hline $\begin{array}{l}\text { Revenue, expenditure, balance and } \\
\text { composition of financing }{ }^{4}-\text { general } \\
\text { government }{ }^{5}\end{array}$ & $12 / 09$ & $06 / 10$ & A & A & A \\
\hline $\begin{array}{l}\text { Revenue, expenditure, balance and } \\
\text { composition of financing }{ }^{4}-\text { central } \\
\text { government }\end{array}$ & $05 / 10$ & $06 / 14 / 10$ & M & M & M \\
\hline $\begin{array}{l}\text { Stocks of central government and central } \\
\text { government-guaranteed debt }\end{array}$ & $12 / 09$ & $06 / 10$ & Q & Q & Q \\
\hline External current account balance & $12 / 09$ & $05 / 10$ & $A, S^{12}$ & $A, S^{12}$ & $A, S^{12}$ \\
\hline Exports and imports of goods and services ${ }^{7}$ & $05 / 10$ & $06 / 10$ & M & M & M \\
\hline GDP/GNP ${ }^{8}$ & $03 / 10$ & $06 / 10$ & $\begin{array}{c}\mathrm{A}, \\
\mathrm{Q} \text { (cumulative) }\end{array}$ & $\begin{array}{c}\mathrm{A}, \\
\mathrm{Q} \text { (cumulative) }\end{array}$ & $\begin{array}{c}\mathrm{A}, \\
\mathrm{Q} \text { (cumulative } \\
\text { ) }\end{array}$ \\
\hline Gross external debt & $12 / 09$ & $06 / 10$ & $\mathrm{~A}, \mathrm{Q}$ & $\mathrm{A}, \mathrm{Q}$ & $\mathrm{A}, \mathrm{Q}$ \\
\hline International investment position & $12 / 09$ & $05 / 10$ & A & A & A \\
\hline
\end{tabular}

${ }^{1}$ Includes reserve assets pledged or otherwise encumbered as well as net derivative positions.

${ }^{2}$ Both market-based and officially-determined, including discount rates, money market rates, rates on treasury bills, notes and bonds.

${ }^{3}$ Only 12-month growth rates are reported (price indices are not available).

${ }^{4}$ Data on financing (foreign, domestic bank, and domestic nonbank financing) is not available.

${ }^{5}$ The general government consists of the central government (budgetary funds, extra budgetary funds, and social security funds) and state and local governments.

${ }^{6}$ Including currency and maturity composition.

${ }^{7}$ Data on the exports and imports of goods are provided monthly. Services trade data is provided semi-annually and released with the current account statistics.

${ }^{8}$ For real GDP, level data are available only on an annual basis (growth rates are available on a quarterly, cumulative basis).

${ }^{9}$ Daily (D), Weekly (W), Monthly (M), Quarterly (Q), Annually (A); Irregular (I); Not Available (NA).

${ }^{10}$ While officially transmitted on a monthly basis, these data are available from news sources on a daily basis.

${ }^{11}$ Interest rates change only infrequently; these changes are publicly announced.

${ }^{12}$ Data provided semi-annually. 


\section{Annex V. China: Fiscal Reforms and Technical Assistance}

1. In recent years, the Fund has provided technical assistance in a number of areas (Table V.1). This annex focuses on the main issues and recommendations in the fiscal area.

\section{Fiscal Technical Assistance Program}

2. FAD has largely provided advice on tax policy, tax administration, budget and treasury reforms, and intergovernmental relations.

\section{Tax Policy}

3. The scope of the Fund TA work in this area has been quite comprehensive, covering every major tax: the value-added tax (VAT), the business tax, the enterprise income tax (EIT), and the personal income tax (PIT), or the tax treatment of specific sectors (i.e., financial sector).

4. On the VAT, the focus of the Fund's TA advice on the VAT has been on transforming it into a consumption-type VAT (now being piloted). As there are important revenue and central-province intergovernmental implications of the VAT reform, the Fund has paid particular attention to alternative transition strategies. The Fund's TA advice has also focused on improving the structure of the EIT, including the unification of the regimes applying separately to domestic and foreign enterprises, and rationalizing and reducing the scope of EIT incentives. The EIT was unified on January 1, 2008. For the PIT, whose yield is still relatively insignificant, its structure should be streamlined and its rates simplified; the authorities have recently increased the PIT income exemption threshold, along the lines of previous Fund's advice. In addition, the liberalization of the financial sector under the WTO commitments has important tax implications, some of which has already been covered by Fund TA; such as the August 2007 mission which advised the authorities on financial taxation. The authorities have also expressed interest in receiving TA on streamlining real estate taxes, which are an important revenue handle for local governments. A mission on revenue forecasting took place in March 2008, and a mission on tax gap estimation is scheduled for June 2009.

\section{Tax Administration}

5. The authorities have been putting in place the basic building blocks of a modern national tax administration. In this regard, the Fund TA program has aimed at assisting the State Administration of Taxation (SAT) to develop the strategic capacity required for it to manage a national tax system, with assistance provided to both the central and provincial governments. During 2006-07, TA covered strategic planning, compliance risk management, business process reengineering, VAT administration, taxpayer services, and the planned IT modernization program, Golden Tax Project 3 (GTP 3). A seminar on strategic planning and management practices in support of previous FAD recommendations was conducted 
January 2008. The SAT has made good progress particularly in VAT administration and delivery of taxpayer services (including the introduction of e-services). Importantly, compliance risk management capacity is under development and a major IT system enhancement is in the beginning stages. Other organizational reforms have proven more difficult, such as implementing a fully functional organization structure with expanded headquarters responsibilities and staffing, and integrating strategic and annual business planning into the SAT's management processes. With the assistance of the Resident Representative in Beijing, the SAT's TA needs for the immediate future have been determined as consolidating the VAT on services, and in large taxpayer compliance programs — both areas will be addressed by FAD during FY2011.

\section{Public Financial Management}

6. In order to improve control, allocation and management of public spending, several budget and treasury reforms have been implemented in recent years. These include: improving budget preparation, especially budget classification; introducing departmental budgets; centralizing the government payments function; and establishing treasury single accounts (TSA) at the central and provincial levels. ${ }^{1}$

7. Up until 2007, these efforts were supported by extensive technical assistance from FAD, which also provided TA for a possible reform of the 1994 Budget Law and on accrual accounting (see Table V.1). Topics for further TA—including for preparing medium-term expenditure frameworks, improving fiscal transparency and macrofiscal forecasting, developing government financial management information systems (GFMISs), and strengthening government cash management - were discussed in 2007. However, the authorities have not yet followed up with requests for TA in any of these areas. In 2009 FAD participated and provided the keynote speech at an international conference in Hainan Province on local government cash management organized by MOF and the ADB. FAD has offered to provide further TA in this area.

\section{Intergovernmental Fiscal Relations}

8. The authorities are aware of the need to reform the system of intergovernmental fiscal relations, as imbalances between the center and subnational levels are growing and regional disparities are widening. There is a need to clarify expenditure mandates, including by centralizing some spending responsibilities such as pensions. Revenue sharing and the design of the transfer system also need to be reformed. In November 2007, FAD organized a conference on "Reforming Assignments and Next Steps in Intergovernmental Reforms" (in Hangzhou) with funding from the UNDP and the Chinese authorities. The authorities

\footnotetext{
${ }^{1}$ A standard Treasury Single Account (TSA) is a centralized bank account or a set of linked bank accounts through which the government, including its entities and spending units, transacts all receipts and payments and consolidates its cash balances. TSA reform has been introduced in all 36 provinces, autonomous regions and municipalities, and is being pursued in some 500 prefectures and larger cities.
} 
confirmed that they have now established a Sub-National Debt Management Division in the Ministry of Finance, and that one of the additional areas of reform will be to assess subnational risks and liabilities. 
Table V.1. China-Summary of Technical Assistance, 2001-09

\begin{tabular}{ll}
\hline \multicolumn{1}{c}{ Department } & \\
\hline Tax System Reform & \\
FAD & Mission on VAT and inheritance tax \\
FAD & Mission on tax preference \\
FAD & Mission on financial sector taxation \\
FAD & Mission on personal income tax reform \\
FAD & Mission on VAT treatment of financial services \\
FAD & Mission on estimation of VAT gap and capacity \\
Tax Administration Reform & \\
FAD & \\
FAD & Five missions on computerizations \\
FAD & Two missions on strategic planning \\
FAD & Seminar on Strategic Planning in Washington \\
FAD & Mission on revenue administration \\
FAD & Review of computerization project \\
FAD & Mission on business process reengineering pilot \\
FAD & Mission on IT modernization \\
& Mission on strategic planning, risk management, and taxpayer \\
FAD & services \\
FAD & Mission on VAT invoice cross-checking and other administration \\
FAD & issues \\
FAD & Mission on business process re-engineering and Golden Tax \\
FAD & Project 3 \\
& Seminar on Strategic Planning and Management \\
Mission on project management Golden Tax Project 3 & Expert visit on strategic planning \\
& \\
&
\end{tabular}

Public Financial Management

$\begin{array}{ll}\text { FAD } & \text { Workshop on Government Fiscal Management Information System } \\ \text { FAD } & \text { Mission on treasury/accounting reform; macrofiscal coordination } \\ \text { FAD } & \text { Mission on budget preparation, classification, and treasury reform } \\ \text { FAD } & \text { Mission on budget classification } \\ \text { FAD } & \text { Workshop on Budget and Treasury Modernization in Washington } \\ \text { FAD } & \text { Mission on treasury and accounting reforms } \\ \text { FAD } & \text { Mission on Budget Law I } \\ \text { FAD } & \text { Mission on cash management } \\ \text { FAD } & \text { Mission on Budget Law II } \\ \text { FAD } & \text { Discuss FAD's PFM program with authorities } \\ \text { FAD/STA } & \text { Mission on Accrual Accounting } \\ \text { FAD } & \text { Seminar on Local Government Cash management }\end{array}$

Intergovernmental Fiscal Relations

$\begin{array}{ll}\text { FAD } & \text { Mission intergovernmental relations } \\ \text { FAD } & \text { Mission on subnational fiscal risks } \\ \text { FAD } & \text { Conference on Reforming Assignments and Next Steps in } \\ & \text { Intergovernmental Reforms }\end{array}$

Statistics

\begin{tabular}{ll} 
STA & Seminar on General Data Dissemination System \\
STA & Missions on trade price statistics \\
STA & Mission on GDDS \\
STA & Seminar on GDDS/SDDS in Washington \\
STA & GDDS Review \\
STA & Mission on government financial statistics \\
STA & Mission on monetary and financial statistic \\
\hline
\end{tabular}

April 2001

September 2001

Aug/Sep 2002

November 2003

April 2006

June 2009

June 2000-Oct. 2002

Nov. 2001-Aug. 2002

October 2002

November 2003

September 2004

November 2005

June 2006

September 2006

March 2007

August 2007

January 2008

October 2009

October 2009

February 2001 November 2001 June 2002

March 2003

October 2003

November 2003

March 2004

April 2006

September 2007

September 2007

September 2007

December 2009

November 2002

November 2003

November 2007
April 2001

Jun. 2001-Jan. 2002

Feb./Mar. 2002

September 2002

December 2003

January 2005

Feb./Mar. 2005 
Table V.1. China-Summary of Technical Assistance, 2001-09 (Continued)

Department

Purpose

Date

Statistics (continued)

$\begin{array}{ll}\text { STA } & \text { Seminar on International Investment Position } \\ \text { STA } & \text { Seminar on IIP Statistics } \\ \text { STA } & \text { Seminar on External Debt Statistics } \\ \text { STA } & \text { Macroeconomic statistics } \\ \text { STA } & \text { Balance of Payments and IIP Course } \\ \text { STA } & \text { Mission on monetary and financial statistics }\end{array}$

Monetary Policy and Bank Supervision

$\begin{array}{ll}\text { MFD } & \text { Missions on banking supervision } \\ \text { MFD } & \text { Bank Restructuring } \\ \text { MFD } & \text { AML/CFT Issues } \\ \text { MFD } & \text { AML/CFT Training for PBC Officials } \\ \text { MFD/LEG } & \text { Mission on AML/CFT } \\ \text { LEG } & \text { AML/CFT Symposia } \\ \text { MFD } & \text { AML/CFT Symposia } \\ \text { MFD } & \text { AML/CFT and Internal Control Workshop } \\ \text { LEG/MFD } & \text { AML/CFT Workshop } \\ \text { LEG/MFD } & \text { Mission on AML/CFT } \\ \text { LEG } & \text { Workshop on Information Management Technology for China's } \\ \text { LEG } & \text { AML } \\ \text { LEG } & \text { Mission on AML/CFT } \\ \text { LEG } & \text { AML/CFT Workshop } \\ \text { LEG } & \text { Mission on AML/CFT } \\ \text { LEG } & \text { Mission on AML/CFT } \\ \text { LEG } & \text { AML/CFT Symposia }\end{array}$

Review of Technical Assistance

$\begin{array}{ll}\text { FAD } & \text { Visit to review UNDP/IMF/China fiscal reform TA program } \\ \text { FAD/TAS } & \text { Two missions for tripartite review of the UNDP/IMF/China fiscal } \\ \text { MFD } & \text { reform TA program } \\ \text { MFD } & \text { Mission on TA needs in banking sector reform } \\ \text { FAD } & \text { Mission on TA needs in financial sector } \\ \text { FAD } & \text { Participation in UNDP/DFID fiscal reform workshop } \\ & \text { Visit to discuss TA needs under UNDP/DFID fiscal reform project }\end{array}$

Training

INS

INS

INS

STA

MFD

MFD

INS

MFD

FAD

STA

STA

INS

MFD
Courses on Financial Programming and Policies (3)

Course on Banking Supervision

High-Level Seminar on Banking Reform

Seminar on Money and Banking Statistics

Course on Banking Supervision (On-Site and Off-Site)

Banking Risk Management

Course on Financial Programming and Policies

Seminar on Capital Account Convertibility

Course on Public Sector Expenditure Management

Seminar on Balance of Payments and IIP Statistics

Course on Government Financial Statistics

Course on Banking Supervision

Central Bank Accounting
April 2005

April 2005

August 2005

May 2006

June 2007

August 2007

October 2003

April 2004

September 2003

February 2005

April 2005

May 2005

September 2005

November 2005

December 2005

April 2006

June 2006

July 2006

July 2006

August 2006

September 2006

October 2006

November 2006

February 2001

Jan. 2002/Feb. 2003

July 2002

October 2003

February 2004

December 2004

July 2000-June 2002

June 2001

March 2001

April 2001

July 2001

July 2001

August 2001

October 2001

June/July 2002

August 2002

September 2002

September 2002

November 2002 
Table V.1. China-Summary of Technical Assistance, 2001-09 (Concluded)

\begin{tabular}{|c|c|c|}
\hline Department & Purpose & Date \\
\hline \multicolumn{3}{|l|}{ Training (continued) } \\
\hline STA & Course on Government Financial Statistics & September 2003 \\
\hline INS & Course on Financial Programming and Policies & October 2003 \\
\hline MFD & Course on Assessing Financial Systems & November 2003 \\
\hline INS & Course on Advanced Financial Programming (Washington) & November 2003 \\
\hline STA & Course on Monetary and Financial Statistics & Nov./Dec. 2003 \\
\hline FAD & International Experience with Budget Law and Budget Law Reform & March 2004 \\
\hline INS & High-Level Seminar on Monetary Policy Transmission & April 2004 \\
\hline INS & High-Level Seminar on China's Foreign Exchange System & May 2004 \\
\hline STA & Seminar on Coordinated Portfolio Investment Survey & April 2004 \\
\hline INS & Course on Financial Market Analysis & June 2004 \\
\hline MFD & Workshop on Ex and Balance of Payments Issues & June 2004 \\
\hline INS & $\begin{array}{l}\text { Course on Macroeconomic Management and Financial Sector } \\
\text { Issues }\end{array}$ & July 2004 \\
\hline STA & Seminar on Quarterly National Accounts & September 2004 \\
\hline INS & Course on Financial Programming and Policies & October 2004 \\
\hline STA & High Level Seminar on Macroeconomic Statistics & January 2005 \\
\hline MFD & Workshop on Monetary Strategy and Operation & May 2005 \\
\hline INS & Course on Financial Programming and Policies & June 2005 \\
\hline INS & Course on Macroeconomic Management and Fiscal Issues & June 2005 \\
\hline LEG & National IT Symposium & July 2005 \\
\hline LEG & AML/CFT Workshop & July 2005 \\
\hline INS & $\begin{array}{l}\text { Course on Macroeconomic Management and Financial Sector } \\
\text { Issues }\end{array}$ & July 2005 \\
\hline STA & Course on External Debt Statistics & August 2005 \\
\hline STA & Course on Monetary and Financial Statistics & September 2005 \\
\hline LEG & Advanced Training on ML and TF Typologies and STRs & December 2005 \\
\hline MFD & Course on Foreign Exchange Operations & March 2006 \\
\hline INS & $\begin{array}{l}\text { Course on Macroeconomic Management and Financial Sector } \\
\text { Issues }\end{array}$ & May 2006 \\
\hline LEG & AML/CFT Workshop & June 2006 \\
\hline MFD & Course on Determining the Intermediate Target for Monetary Policy & June 2006 \\
\hline STA & Seminar on Banking Statistics on Cross-Border Flows & June 2006 \\
\hline INS & Course on Advanced Financial Programming & July 2006 \\
\hline INS & Course on Macroeconomic Management and Financial Issues & July 2006 \\
\hline LEG & National Workshop on IT for FIUs & September 2006 \\
\hline LEG & Workshop for APC Countries & December 2006 \\
\hline LEG & AML/CFT Workshop & May 2007 \\
\hline LEG & AML/CFT Training for Supervisors & May 2007 \\
\hline INS & Course on Financial Programming and Policies & May 2007 \\
\hline STA & Course on Balance of Payments Statistics & June/July 2007 \\
\hline INS & $\begin{array}{l}\text { Course on Macroeconomic Management and Financial Sector } \\
\text { Issues }\end{array}$ & July 2007 \\
\hline LEG & AML/CFT Training for Supervisors & October 2007 \\
\hline STA & Course on Monetary and Financial Statistics & October 2007 \\
\hline MCM & Workshop on FSAP and Financial Stability & December 2007 \\
\hline MCM & Workshop on Stress Testing & December 2007 \\
\hline LEG & AML/CFT Risks in the Casino Sector & December 2007 \\
\hline FAD & Seminar on Revenue Forecasting & March 2008 \\
\hline LEG & AML/CFT Workshop & January 2008 \\
\hline
\end{tabular}




\section{Statement by the IMF Staff Representative on the People's Republic of China July 26, 2010}

The following information has become available following the issuance of the staff report. It does not alter the thrust of the staff appraisal.

1. Recent data. Latest data releases indicate growth is on track to reach into the double digits this year, while inflationary pressures are abating.

Real GDP growth slowed to 101/4 percent year-on-year in the second quarter of 2010, down from 11.9 percent in the first quarter. This is in line with staff forecasts. Investment and a rebound in net exports were the main drivers of growth in the second quarter.

- Consumer and producer price inflation eased in June as food and commodity price inflation slowed.

- $\quad$ The trade surplus grew in June to US\$ 20 billion. As in May, export

\begin{tabular}{llllll}
\hline & \multirow{2}{*}{2009} & \multicolumn{5}{c}{2010} \\
\cline { 3 - 6 } & & Q1 & Apr & May & Jun \\
\hline \multirow{2}{*}{ CPI inflation (y/y, eop) } & 1.9 & 2.4 & 2.8 & 3.1 & 2.9 \\
PPI inflation (y/y, eop) & 1.7 & 5.9 & 6.8 & 7.1 & 6.4 \\
& & & & & \\
\hline Sources: CEIC database. & & & & &
\end{tabular}
growth continued to outpace imports.

- Gross official reserves were broadly flat in the second quarter at US\$2.45 trillion.

- $\quad$ Provisioning for nonperforming loans rose to 186 percent by end-June.

2. Property Market. There are signs the government's measures to cool off the property market have started to have an impact with sales volumes continuing to be low and a slowdown in residential property prices in the major cities.

3. Exchange Rate. In the four weeks following the return to the pre-crisis managed floating system, the exchange rate has appreciated by about $3 / 4$ percent against the U.S. dollar and depreciated by $3 / 4$ percent in nominal effective terms.

4. IPOs. Agricultural Bank of China was listed in both Shanghai and Hong Kong SAR. Proceeds from the dual listing were US\$19.2 billion.

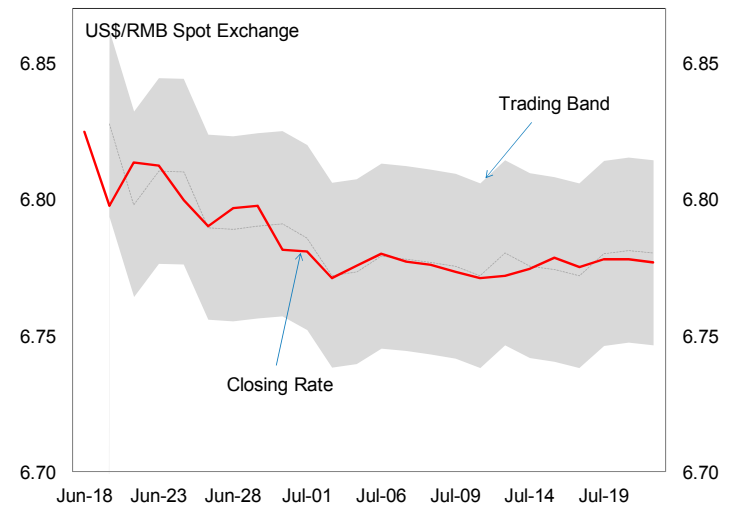


Public Information Notice (PIN) No. 10/100

FOR IMMEDIATE RELEASE

July 27,2010
International Monetary Fund $70019^{\text {th }}$ Street, NW

Washington, D. C. 20431 USA

\section{IMF Executive Board Concludes 2010 Article IV Consultation with China}

On July 26, 2010, the Executive Board of the International Monetary Fund (IMF) concluded the Article IV consultation with China. ${ }^{1}$

\section{Background}

China was hit hard by the global financial crisis. However, the authorities quick, determined, and effective policy response has helped mitigate the impact on the economy and ensured that China has led the global recovery.

Public infrastructure spending was quickly increased, taxes were lowered, the government put in place incentives to boost purchases of consumer durables, and pensions, social transfers, healthcare and education spending were all raised. At the same time, interest rates and reserve requirements were lowered and limits on credit growth were removed, leading to an extraordinary surge in bank lending.

These policies were instrumental in arresting the downward momentum to both activity and confidence. Growth began to pick up in the second quarter of 2009 and reached an average

\footnotetext{
${ }^{1}$ Under Article IV of the IMF's Articles of Agreement, the IMF holds bilateral discussions with members, usually every year. A staff team visits the country, collects economic and financial information, and discusses with officials the country's economic developments and policies. On return to headquarters, the staff prepares a report, which forms the basis for discussion by the Executive Board. At the conclusion of the discussion, the Managing Director, as Chairman of the Board, summarizes the views of Executive Directors, and this summary is transmitted to the country's authorities.
} 
for the year of 9.1 percent. Inflation moved into negative territory for much of 2009 but has since registered a modest increase, the bulk of which has been directly attributable to higher food prices. In the 12 months to May, the nominal effective exchange rate has depreciated by $11 / 4$ percent while the real effective exchange rate has depreciated by 0.1 percent.

China's recovery had significant positive spillovers to the region and the global economy, initially through increased demand for commodities-contributing to an upswing in global commodity prices-and later through higher imports of capital goods. The balance of payments saw a dramatic shift with the current account falling quickly as exports slowed and imports surged. Despite the lower current account, reserve accumulation has continued to be rapid.

With the recovery becoming increasingly well established, the government has begun to unwind some of its crisis response measures. Credit growth has been slowed, reserve requirements were modestly increased, and prudential requirements related to property lending were tightened. The government also announced that it was returning to the managed floating regime that had been in place from July 2005 to July 2008. Fiscal policy, however, continues to provide important support to the economy.

\section{Executive Board Assessment}

Executive Directors commended China's proactive and decisive policy response to the global economic crisis. Growth is expected to continue to be robust, while the inflation outlook appears benign. The policy challenge now is to calibrate the pace and sequencing of exit from the fiscal stimulus and credit expansion, while making further progress in reorienting the economy toward private consumption. Directors commended the Chinese authorities for their commitment to the G-20 framework for strong, sustainable, and balanced growth.

Directors considered it appropriate that the 2010 budget maintains support for a steady resumption of private demand. They saw room for further reorientation of the stimulus package toward measures that promote private consumption, raise household income, lessen income inequality, and improve the social safety net, building on recent progress. Directors supported a gradual phase out of the fiscal stimulus in 2011, provided the current trajectory for the economy is maintained.

Directors agreed that the targeted reduction in broad money growth this year balances well the need to provide continued support to the economy with the desire to safeguard the health of bank balance sheets. They encouraged the authorities to rely more on market-based instruments to achieve this goal, including via open market operations, higher interest rates, and reserve requirements. Directors highlighted the need for regulatory and supervisory vigilance to manage any deterioration in credit quality, and for increased transparency in lending to local government financing vehicles. At the same time, it would also be important to continue to liberalize the financial system; the ongoing FSAP will provide useful guidance for the content and sequencing of the necessary reform measures. 
Directors welcomed the recent decision to return to the managed floating exchange rate regime. This decision will increase the central bank's flexibility to tighten monetary conditions. Several Directors agreed that the exchange rate is undervalued. However, a number of others disagreed with the staff's assessment of the level of the exchange rate, noting that it is based on uncertain forecasts of the current account surplus. Many Directors stressed that, over time, a stronger renminbi would help facilitate a shift from exports and investment to private consumption as the principal driver of economic growth. A number of Directors pointed to signs that a structural shift in the balance of payments is already underway, reflecting the reforms already put in place to strengthen consumption.

Directors commended the government for its pragmatic deployment of a range of countervailing prudential measures to contain property price inflation. Additional measures could be needed to address the fundamental causes of property price inflation, possibly including consideration of a property tax and broader financial market development to provide alternative savings vehicles.

Directors commended the authorities for the progress made in building a more effective system of social insurance. They encouraged further steps to improve health care, expand pension coverage, foster labor mobility, and reduce corporate savings.

Public Information Notices (PINs) form part of the IMF's efforts to promote transparency of the IMF's views and analysis of economic developments and policies. With the consent of the country (or countries) concerned, PINs are issued after Executive Board discussions of Article IV consultations with member countries, of its surveillance of developments at the regional level, of post-program monitoring, and of ex post assessments of member countries with longer-term program engagements. PINs are also issued after Executive Board discussions of general policy matters, unless otherwise decided by the Executive Board in a particular case. 
Table 1. China: Selected Economic Indicators

\begin{tabular}{|c|c|c|c|c|c|c|}
\hline & 2005 & 2006 & 2007 & 2008 & 2009 & $\frac{2010}{\text { Proj. }}$ \\
\hline & \multicolumn{6}{|c|}{ (Annual percentage change, unless otherwise specified) } \\
\hline \multicolumn{7}{|l|}{ National accounts and employment } \\
\hline Real GDP & 11.3 & 12.7 & 14.2 & 9.6 & 9.1 & 10.5 \\
\hline Total domestic demand & 9.2 & 11.5 & 12.7 & 9.7 & 14.8 & 11.5 \\
\hline Consumption & 8.1 & 9.8 & 11.1 & 8.6 & 9.9 & 13.2 \\
\hline Investment & 10.6 & 13.6 & 14.7 & 11.0 & 20.4 & 9.7 \\
\hline Fixed & 11.9 & 12.8 & 13.4 & 9.7 & 24.6 & 10.1 \\
\hline Inventories $1 /$ & -0.3 & 0.6 & 0.8 & 0.8 & -1.0 & 0.0 \\
\hline Net exports $1 /$ & 2.6 & 2.0 & 2.5 & 0.8 & -4.3 & -0.5 \\
\hline \multicolumn{7}{|l|}{ Consumer prices } \\
\hline End of period & 1.4 & 2.0 & 6.6 & 2.5 & 0.7 & 3.5 \\
\hline Average & 1.8 & 1.5 & 4.8 & 5.9 & -0.7 & 3.5 \\
\hline \multirow[t]{2}{*}{ Unemployment rate (annual average) } & 4.2 & 4.1 & 4.0 & 4.2 & 4.3 & 4.1 \\
\hline & \multicolumn{6}{|c|}{ (In percent of GDP) } \\
\hline \multicolumn{7}{|l|}{ External debt and balance of payments } \\
\hline Current account & 7.1 & 9.3 & 10.6 & 9.6 & 6.0 & 5.0 \\
\hline Trade balance & 5.9 & 8.0 & 9.0 & 8.0 & 5.0 & 4.0 \\
\hline Exports of goods & 33.8 & 35.7 & 34.9 & 31.7 & 24.1 & 30.3 \\
\hline Imports of goods & 27.8 & 27.7 & 25.9 & 23.8 & 19.1 & 26.3 \\
\hline Gross external debt & 13.1 & 12.5 & 11.1 & 8.6 & 8.6 & 8.9 \\
\hline \multicolumn{7}{|l|}{ Saving and investment } \\
\hline Gross domestic investment & 42.1 & 43.0 & 41.7 & 44.0 & 47.7 & 50.0 \\
\hline National saving & 49.2 & 52.3 & 52.4 & 53.7 & 53.6 & 55.0 \\
\hline Government & 6.3 & 8.7 & 10.5 & 9.9 & 9.9 & 8.8 \\
\hline Non-Government & 42.9 & 43.6 & 41.9 & 43.8 & 43.7 & 46.2 \\
\hline \multicolumn{7}{|l|}{ Public sector finance } \\
\hline General government gross debt & 17.6 & 16.5 & 19.8 & 16.8 & 18.6 & 20.1 \\
\hline \multirow[t]{2}{*}{ General government balance } & -1.4 & -0.7 & 0.9 & -0.4 & -3.0 & -3.0 \\
\hline & \multicolumn{6}{|c|}{ (Annual percentage change) } \\
\hline Real effective exchange rate & -0.3 & 2.2 & 5.0 & 8.5 & 2.7 & \\
\hline
\end{tabular}

Sources: CEIC Data Co., Ltd.; and staff estimates and projections.

$1 /$ Contribution to annual growth in percent. 